\title{
A Methodological Proposal for Implementing Demand-Shifting Strategies in the Wholesale Electricity Market
}

\author{
Máximo A. Domínguez-Garabitos ${ }^{1, *}$, Víctor S. Ocaña-Guevara ${ }^{1,2}$, Félix Santos-García ${ }^{1,2}$,

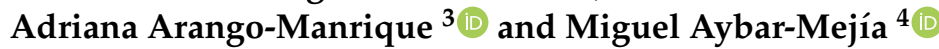

1 Basic Sciences, Instituto Tecnológico de Santo Domingo, Santo Domingo 10602, Dominican Republic; victor.ocana@intec.edu.do (V.S.O.-G.); felix.santos@intec.edu.do (F.S.-G.)

2 Centre for Energy Studies and Environmental Technologies (CEETA), Carretera a Camajuaní Km 5 1/2, Universidad Central "Marta Abreu" de Las Villas, Villa Clara 50100, Cuba

3 Department of Electrical and Electronic Engineering, Universidad del Norte, Barranquilla 080001, Colombia; adrianaarango@uninorte.edu.co

4 Engineering Area, Instituto Tecnológico de Santo Domingo, Santo Domingo 10602, Dominican Republic; miguel.aybar@intec.edu.do

* Correspondence: maximo.dominguez@intec.edu.do; Tel.: +1-829-213-6281

Citation: Domínguez-Garabitos,

M.A.; Ocaña-Guevara, V.S.;

Santos-García, F.; Arango-Manrique,

A.; Aybar-Mejía, M. A

Methodological Proposal for

Implementing Demand-Shifting

Strategies in the Wholesale Electricity

Market. Energies 2022, 15, 1307

https://doi.org/10.3390/en15041307

Academic Editor: Jesús

Manuel Riquelme-Santos

Received: 20 January 2022

Accepted: 9 February 2022

Published: 11 February 2022

Publisher's Note: MDPI stays neutral with regard to jurisdictional claims in published maps and institutional affiliations.

Copyright: (C) 2022 by the authors. Licensee MDPI, Basel, Switzerland. This article is an open access article distributed under the terms and conditions of the Creative Commons Attribution (CC BY) license (https:// creativecommons.org/licenses/by/ $4.0 /$ )

\begin{abstract}
The energy transition has shown that fossil generation can be complemented with renewable energy and other resources capable of providing flexibility to the energy system's operation, in compliance with the wholesale electricity market's rules. This paper proposes a market-based methodology for introducing flexible demand in the energy dispatch, optimizing the scheduling of electricity system operation in the short-term, and considers the challenge of implementing an incentive scheme for participants in demand-response programs. The scheme includes the criteria of the elasticity of substitution and a renewable energy quota. This methodology is focused on a strategic demand shift to minimize the cost of supply; increase the dispatch of renewable energy; control $\mathrm{CO}_{2}$ emissions; and satisfy the generation, demand, and transmission operating constraints. These conditions encourage the development of a simulation tool that allows a sensitivity analysis to aid decision-making by operators and agents. The proposed methodology optimizes the operational cost of generation supply and specific performance indicators to determine the percentages of demand shift, the amount of $\mathrm{CO}_{2}$ emissions, the ratio of unserved power, the demand benefits obtained from an incentive scheme, and the natural market behavior.
\end{abstract}

Keywords: demand response; elasticity of substitution; renewable energy; wholesale electricity market

\section{Introduction}

This paper proposes an alternative methodology for evaluating the economic and environmental effects of applying an incentive-based demand-response program (DRP) based on load-shifting strategies. The fundamental criteria that allow the demand flexibility of resources are determined by employing demand segmentation and the constant elasticity of substitution (CES). This methodology considers the declared availability profiles for variable renewable energy production, maximizing its contribution. Additionally, the supply costs are minimized, in accordance with the constraints determining the generation, grid, and demand conditions. Limits are established for unserved energy and the displacement of fossil generation, and the reduction in $\mathrm{CO}_{2}$ emissions is also evaluated.

Considering that demand can provide operational flexibility, demand response (DR) has been defined as the ability to modify the profile of electricity consumption based on changes in price signals or incentives applied in the electricity market in order to induce the rational use of electricity and to mitigate vulnerable scenarios that threaten the reliability of the electricity supply in the system $[1,2]$. The benefits of DR involve additional revenue 
and energy efficiency for the provider and the increased reliability and optimization of the electricity infrastructure for all market players. The fundamental functions of DR include demand-increase and -decrease activities utilizing load control and other integrated resources, such as onsite generation and storage [3], allowing the injection of surpluses into the grid. There are two strategies used in power system operation to meet demand projections. One of these seeks a solution to the generation dispatch problem, and the other focuses on the flexibility and availability of resources on the demand side [4]. In the second case, utility providers and large consumers implement efficiency and load-management programs, since flexible demand is seen as a way to mitigate the challenges of increasingly volatile renewable energy sources (RESs), as it can ensure the security of supply [5,6]. The fundamental goal of DR is to control the demand and move it along the time axis according to the generation availability $[7,8]$.

In [9], a DR program for Singapore's wholesale electricity market was investigated. The study included the constraints and modeling of an incentive payment mechanism. The scheme proposed in [9] restricted the flexibility in response to price signals, limiting the maximization of the DR benefits, in contrast to what is proposed in this paper. The authors of [10] present a mathematical model of the application of DR at the individual-household, aggregate-household, network, and market levels. Their approach left open the discussion of possible barriers related to market structure and policies; these are addressed in the proposal of this paper, which points out an opportunity to mitigate deviations in dispatch operation programs.

According to [11], DR can be adapted to offer the following products and services to the power system:

- $\quad$ Firm capacity during peak hours.

- Delivery of energy from electricity generators to consumers under minimum cost conditions.

- Ancillary services to support grid stability.

- A temporary reinforcement of congested elements in transmission networks (TNs) and distribution networks (DNs).

As a management activity, DR categorization addresses the resources required for its implementation, which are subject to dispatch and discretionary conditions, as is illustrated in Figure 1.

Energy resources that are not classified as own-generation activities are often considered unconventional energy sources, allowing various services in electricity markets to be structured based on operational flexibility [12]. DR and energy storage (ES) are nongeneration techniques developed to complement the integration of high levels of variable renewable energy [13], allowing safe and efficient operation [14]. Nowadays, technologies and markets experience significant changes when implementing DR programs, due to the future development needs of multienergy systems, where electricity, natural gas, and other forms of energy participate in a new concept called integrated DR or energy hubs [15]. The process of energy transition experienced in the Wholesale Electricity Market (WEM) is becoming more common today, since the greater dissemination of renewables and DR programs has created awareness of the effect that electricity demand has on the environment and economy among those who are willing to change their load profile to improve the performance of the system, minimizing the operating cost and maximizing the reliability.

The objective of this analysis is to put into context new possibilities for optimizing the operation of energy systems and the electricity market based on DR programs and other resources that have only been studied separately or have been poorly combined, such as the technique of segmenting demand profiles by type of user, the reference values of the elasticity of substitution with extensive implementation of Non-Conventional Renewable Energy (NCRE), and the probabilistic indices for assessing the security of a supply. The main contributions of this paper are the following: 


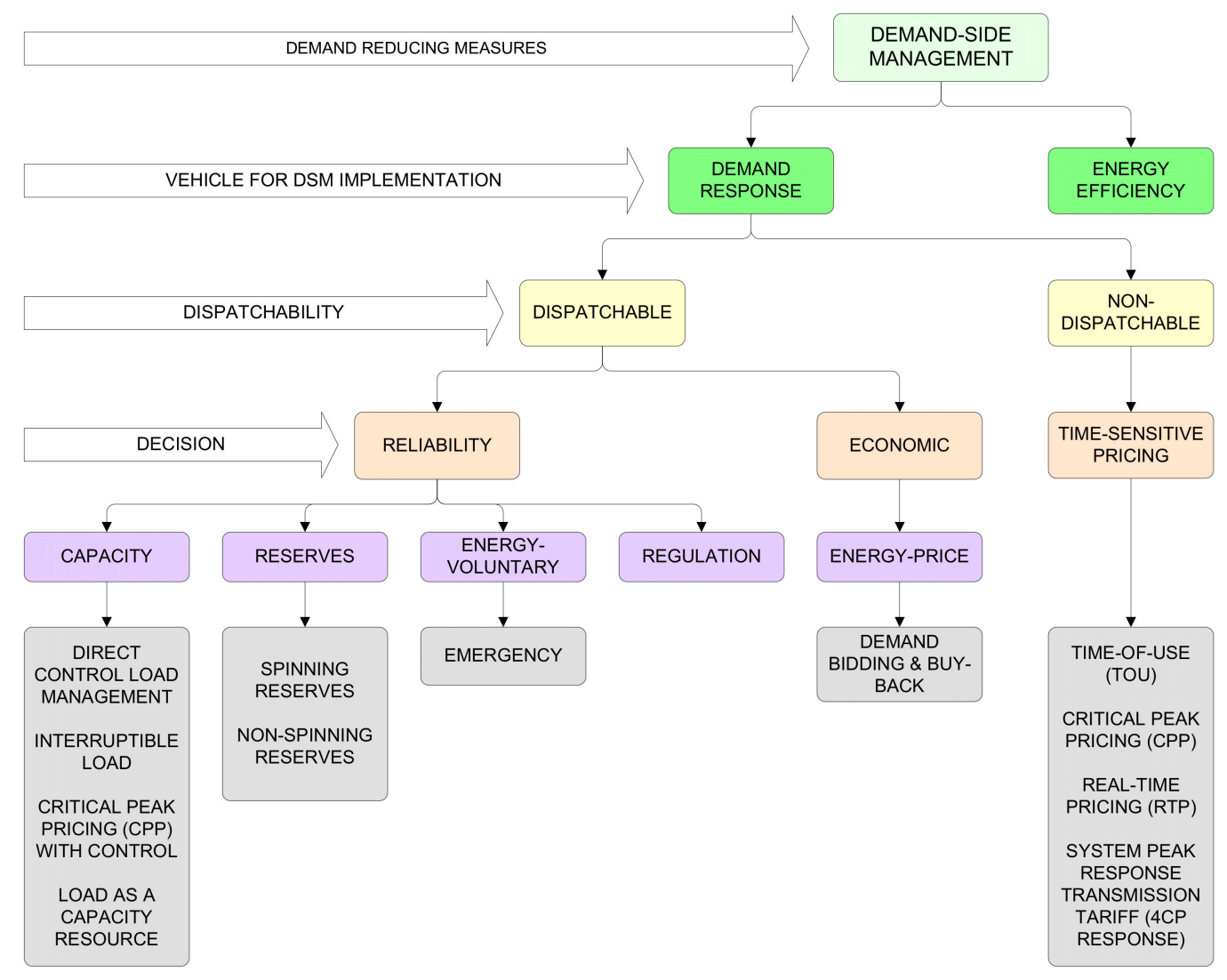

Figure 1. Demand-response categories [1].

- A methodology for evaluating the optimal operating cost of a generation supply in the short-term, emphasizing the proliferation of variable renewable energy and the integration of flexible demand that incentivizes users to shift their load profile according to the constant elasticity of substitution determined by the market operator.

- The definition of the specifications for building a simulation tool to mitigate deviations in the scheduling of an electric system's operation, avoiding cost overruns due to forced generation dispatch.

- The identification of performance indicators by optimizing energy prices and quantities in the market, based on criteria associated with demand-response programs and the constant elasticity of substitution (CES) function.

This paper is structured as follows: Section 2 presents the structure and planning criteria of the wholesale electricity market, including demand-response programs; Section 3 describes flexible demand-side resources, with an emphasis on strategies for modifying electric load profiles and DR program specifications; Section 4 presents the applicability of indicators for assessing DR programs; Section 5 explains the methodologies used to model the demand-response and sustainability dimensions; Section 6 discusses the expected results of the proposed methodology; and finally Section 7 provides conclusions related to the contributions, limitations, and future directions of the study.

\section{Wholesale Electricity Market: Structure and Planning Criteria Using Demand Response}

The conceptual map shown in Figure 2 illustrates how to incorporate flexibility in the operation of a power system, considering the effect of an active DR in the WEM. DR programs require the adjustment of the system's operating plan to ensure a minimum cost, subject to market rules. This section is focused on explaining the links between DR programs and the planning criteria that control the minimum cost of the operation. 


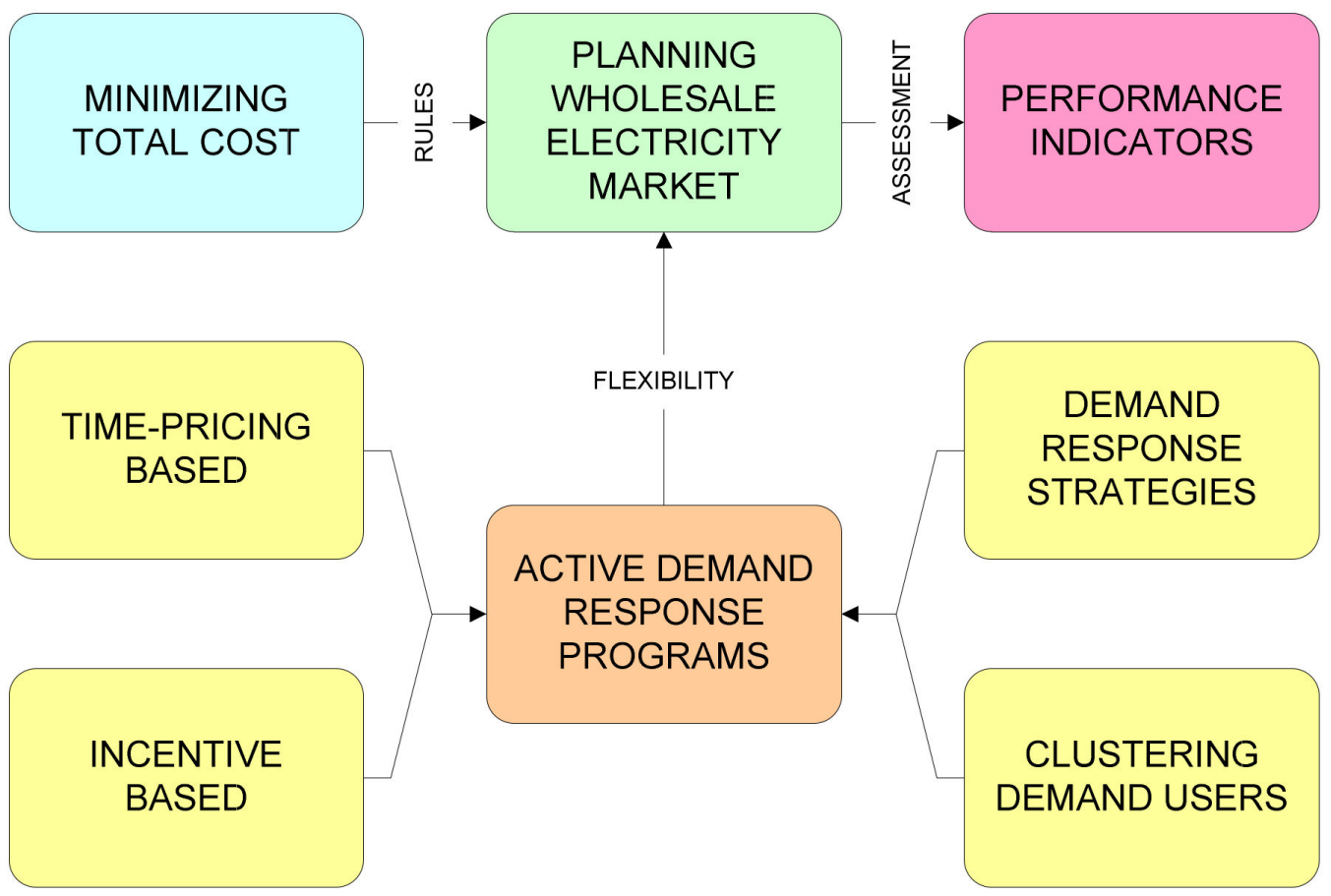

Figure 2. Conceptual map of wholesale electricity market plan implementing demand response.

A unidirectional sequence of activities supports the traditional electricity business model. In this scheme, the generators sell their energy on the WEM, electricity is transported and distributed under the control of a system operator, and retailing companies buy in bulk and sell to end-users. The adequacy of the system and the provision of ancillary services that support the reliability, efficiency, and quality of the services (such as frequency and reactive energy regulation) are mainly ensured by generators and some large consumers. The regulator establishes rules and monitors compliance, while the market operator values the purchases and sales of electricity, ancillary services, and other complementary regulatory mechanisms implemented.

According to [16], "Traditionally, electricity supply was a vertically integrated industry in which the same company conducted all four major activities (generation, transmission, distribution and retailing)". The restructuring of the electric power industry has been established in several countries since the 1990s, shifting from a vertically integrated monopoly into a competitive market. In Figure 3, the relations between these activities and institutions are shown.

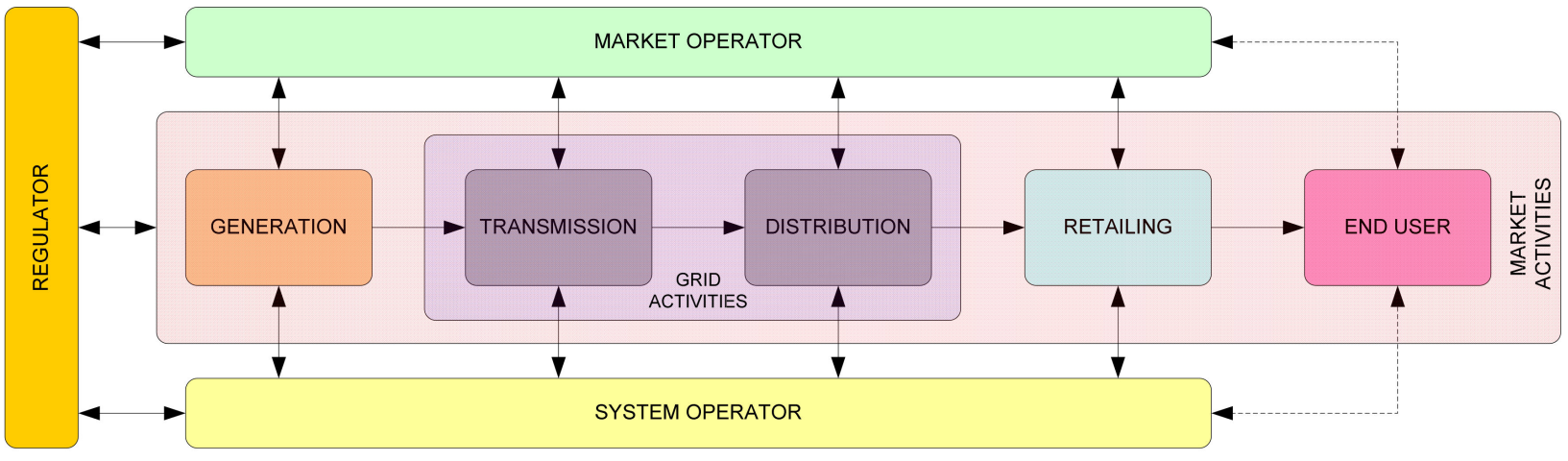

Figure 3. Traditional wholesale electricity market.

DR planning in WEMs was promoted in the United States following the California energy crisis in 2004, and system operators in Europe started to implement it in 2005 [6]. 
In [17], it was concluded that the influence of DR on a WEM is more effective in a market that integrates $\mathrm{CO}_{2}$ costs and subsidies with nonpolluting technologies in the long term. Therefore, without proper DR planning, the effect of DR on the energy system/market may not represent a substantial improvement [18].

Integrating energy resources, ES technologies, and DR have allowed emerging networks to implement flexibility criteria [19]. In [20], the storage and service-control criteria are used to assess the demand flexibility in the residential and commercial sectors.

In [21], the authors explain in physical terms the options that exist to support flexibility mechanisms in power systems and ensure the balance of generation and demand in real time. On the supply side, they make reference to ramp-capacity resources in conventional power plants, flexible generation, the diversification of the generation mix, etc. On the demand side, the variety of options includes DR and energy-efficiency programs. The demands can be managed with storage; EVs; and residential, commercial, and industrial user loads. In the case of networks, flexibility options would allow reconfigurations, meshed topologies, and the incorporation of technologies that allow for smart grid use.

The effect of applying flexibility mechanisms on the market may be permanent or temporary. The first case pertains to the establishment of policies that prescribe fixed or mandatory resources or programs (e.g., energy efficiency), and the second case is more oriented towards short-term mechanisms that can safely minimize a power system's operational costs (e.g., DR programs).

There are multiple challenges to integrating variable renewable energy with market economics and system operation. However, we can consider as a case study Ireland's power system, in which trials have concluded that renewable and flexible technologies, including wind energy, photovoltaic solar energy, demand-side management, and battery storage, are admissible together with conventional generation [22].

With the deployment of flexible resources in the market, it is necessary to create new mechanisms and business models to improve the performance of reserves and flexible ramps. In this context, the authors of [23] describe a contracting methodology designed to respond optimally to aggregate demand. In structural terms, new roles within the WEM have had to be defined, as observed in the markets that include the figure of the aggregator (Figure 4). To illustrate this case of the adaptation of the traditional operation of an electrical system's activities, the aggregator is responsible for managing distributed energy resources (DER) as a new market participant.

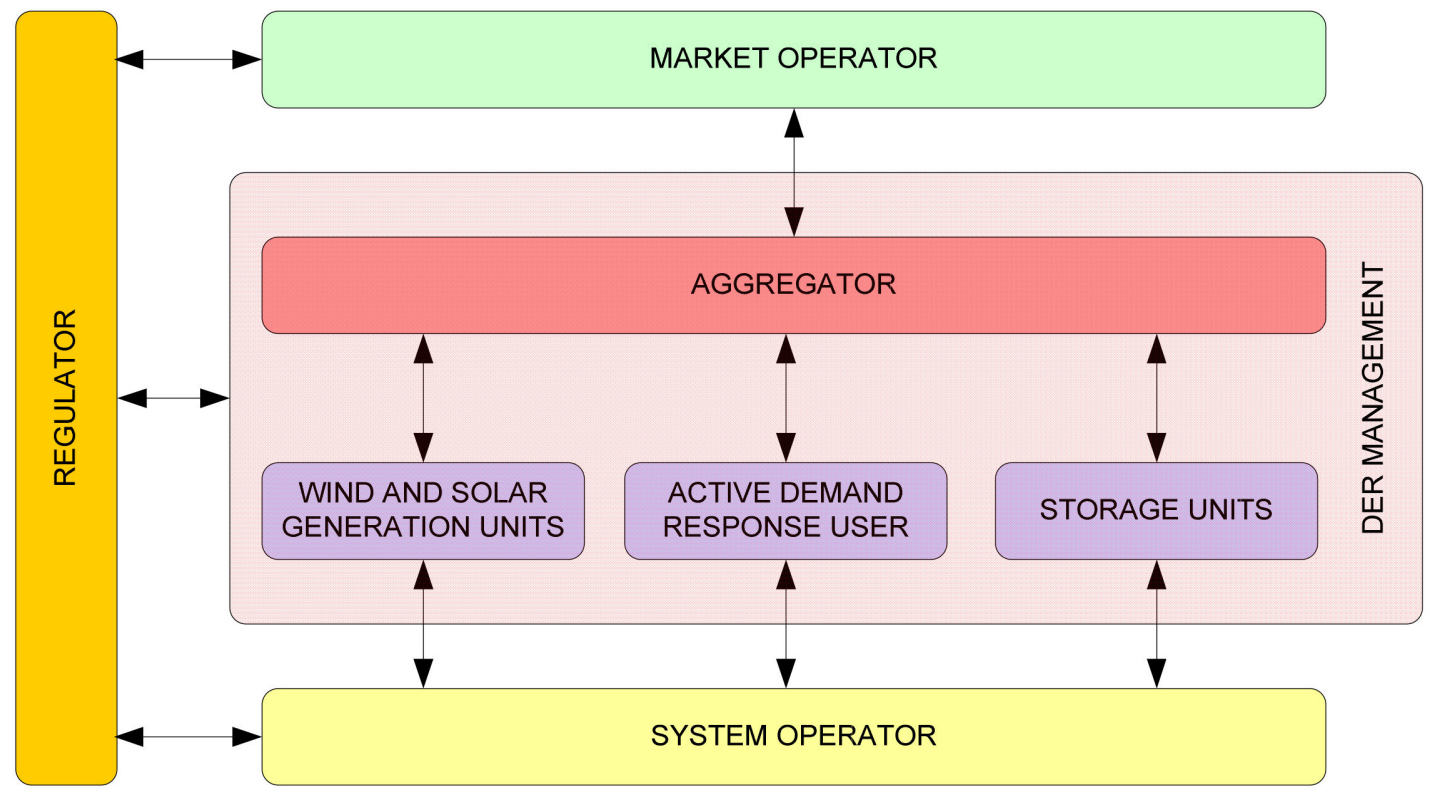

Figure 4. The adaptation of the wholesale electricity market. 
Aggregators are mediators that offer DR services to market participants, system and market operators, and end-users [24,25]. The activity of the aggregator allows small groupings of consumers, producers, and prosumers to participate in the electricity market as a single entity, improving the operational flexibility of the system by managing and commercializing demand and generation resources. Figure 4 illustrates the role of aggregators, showing their value, their coordination with distribution system operators (DSO), and how they can reduce market costs [26-29]. The proposed methodology is focused only on WEM activities and does not consider the internal coordination that the aggregator must carry out with end-users

We conducted a literature review focusing on investigations associated with the model in Figure 4. The authors of [30] indicate that residential customers can implement DR through household appliances such as refrigerators; freezers; washing machines; dryers; and HVAC (heating, ventilation, and air conditioning) systems. In [31], the authors present a business model that includes the figure of the aggregator as a price taker in energy markets and reserve services through the charging and discharging of EVs. The participation of the aggregator in the European energy balance markets is examined in [32]. Different contract-modeling strategies for the aggregator in the market, such as load cuts, load shifting, distributed generation, and ES, are presented in [33].

In situations of congestion and failure to provide ancillary services, or when it does not have the availability of energy required, the aggregator may incur additional penalties and costs for transferring energy from one point to another [34,35]. It should be noted that congestion problems in DNs can influence TNs, causing congestion and the formation of zonal prices. In [27], the economic fundamentals of the aggregator are assessed; the paper evaluates technological and regulatory scenarios, characterizing the added value from a transitory and opportunistic perspective.

The evolution of competitive electricity markets and the advancements in communication technology and control engineering have created the conditions for the development of smart grids, motivating a reformation of the conventional DSM theoretical framework [36]. The main DSM concepts are associated with energy efficiency and DR. Several works have shown that DR contributes to system stability, service quality, the security of supply, and better market operation performance. Some authors use the terminology of Demand Side Integration (DSI) to refer to the modern concept of DSM [4]. As DR is associated with DSI, we also considered integrated resource planning, reliability, security, and electricity prices.

\section{The Demand as a Flexible Resource}

\subsection{Strategies to Modify Load Profiles}

The management of electricity load profiles is based on several strategies for adjusting demand curves based on conditioning mechanisms, such as peak clipping, valley filling, load shifting, strategic load increase, strategic conservation, and flexible load [37,38]. Another strategy for modifying load profiles and their impact on marginal prices and the cost of supply is controlling onsite generation, as verified in the study conducted by the authors of [39]. The broad objectives of the six ways of altering load shapes from the demand side are illustrated in Figure 5.

According to the authors of [4], the mechanisms of peak clipping, valley filling, load shifting, and strategic load growth are associated with dynamic demand-side management terminology (DDSM) and the mechanisms of strategic conservation and flexible load shape with static demand-side management (SDSM). Users adopt different energyconsumption patterns in the dynamic scheme, although the electrical system parameters remain unchanged. In the case of the static scheme, users adopt fixed consumption patterns as long as the electrical system parameters do not show substantial variations [40]. The application of these strategies requires adaptations in the grid to incorporate automatisms capable of triggering cuts, increases, reductions, and displacements of demand, motivating the conformation of the intelligent grid [40]. A brief description of each strategy is shown below: 


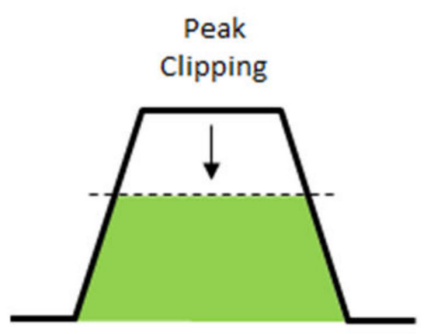

Strategic

Conservation

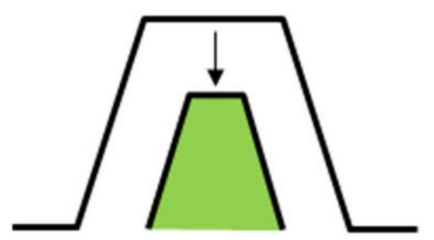

Valley

Filling

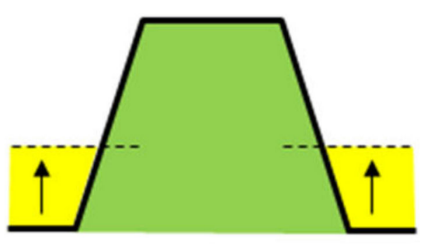

Strategic Load

Growth

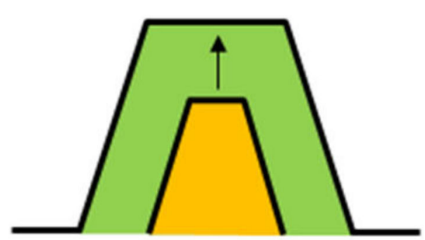

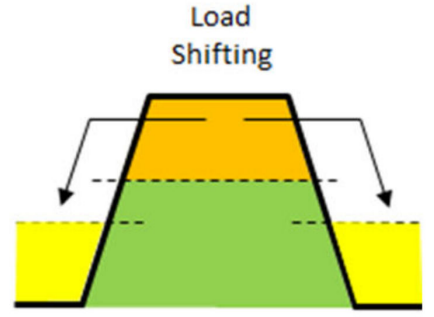

Flexible Load Shape

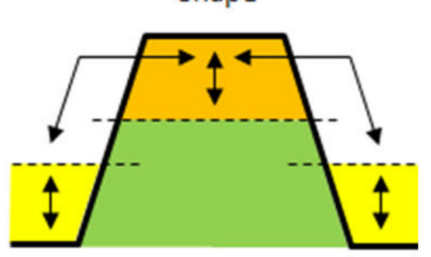

Figure 5. Objectives of demand-response strategies.

\subsubsection{Peak Clipping}

This mechanism reduces loads by opening circuits during peak demand periods, delaying new investment requirements in generation technology due to a net reduction in demand. Usually, its implementation is carried out through the direct load control (DLC) of actuation devices that require automatic communication systems or actions provided directly by the consumer [37].

\subsubsection{Valley Filling}

This strategy involves building up loads at off-peak times, typically encouraged by cheap off-peak tariffs. The energy resources used for filling valleys are varied and include the planning and programming of domestic, industrial, and commercial loads, such as household appliances, battery-based storage systems, heating and cooling equipment, and EVs [37]. As electricity prices are lower in off-peak periods, the strategy takes advantage of the opportunity to increase consumption and consumer profits. Additionally, it improves the load factor of the system, compensating for the losses generated by consumption at the peak and shoulder periods of the daily load curve [41].

\subsubsection{Load Shifting}

The load-shifting strategy provides flexibility for utility companies, allowing schedule changes by moving partial loads from peak to off-peak hours, depending on low electricity prices. Unlike energy-efficiency programs that seek a general reduction in demand, loadshifting mechanisms take advantage of the price difference. Programs based on time-of-use pricing (TOU) and real-time pricing are ideal for this type of strategy [42].

\subsubsection{Strategic Load Growth}

An increase in consumption represents the possibility of guaranteeing supply with other sources of energy [43]. With the restructuring of the electricity industry, strategic load growth has not been favored in the face of minimizing the cost of supplying markets, limiting its use in regions that are able to take advantage of integrating renewable energy on the demand side [44].

\subsubsection{Strategic Conservation}

Strategic conservation applies load-reduction methods to the facilities of the electricity service user through optimization mechanisms [45]. Usually, utility providers do not use this type of strategy in their demand-management programs because a reduction in 
electricity sales caused by this action does not always represent a reduction in the maximum demand for the system.

\subsubsection{Flexible Load}

The flexible load shape is equivalent to combining peak clipping, valley filling, and load shifting. This modification of the daily load curve is more complicated for the system operator in terms of planning and operation. However, it responds with more elasticity depending on the end-user's needs [46]. An advantage of this practice is the value added to the system's reliability by identifying a flexible demand, especially during peak periods [47]. Reducing demand through this scheme allows grid operators to interrupt loads, with consequent changes in the reliability and quality of the service [43]. The technological equipment applied with this technique can be autonomous or manually activated, employing controllable energy-management systems [37].

\subsection{Demand-Response Programs}

The design of DR programs is oriented towards one of two main groups, called price-based programs and incentive-based programs. In price-based programs, electricity customers modify their electricity-consumption pattern in response to the WEM price. In the case of incentive-based programs, a mechanism is structured to provide an economic stimulus based on the participants' performance.

\subsubsection{Price-Based DR (Time-Sensitive Pricing)}

Time-of-use (TOU) pricing, critical peak pricing (CPP), real-time pricing (RTP), and peak-time rebate (PTR) are rate schemes employed by price-based programs that provide economic signals to influence the reduction in energy consumption during peak periods due to the high prices that electricity reaches [48]. Price-responsive programs operate on passive demand, based on voluntary actions by electricity consumers. Brief details for each case are shown below.

\section{Time-of-Use (TOU) Pricing}

In this program, the expected changes in the electricity consumption profile are conditioned by the prices set for each time block. Regularly, usage rates vary over several periods within a day. A typical scheme defines the daily peak, shoulder, and valley prices according to the pattern of the daily load curve [1]. Time-of-use tariffs for the consumption of electricity motivate users to change their habits to take advantage of lower prices, reducing peak demand for electricity at critical times [49].

In the case of Malaysia, most consumers prefer static TOU rates applied in pricebased DR programs due to the transition processes they must face with retailers when formalizing plan changes [18]. A case study based on price responsiveness has been modeled on residential electricity demand, combining a TOU policy with a block pricing policy, verifying that this can help reduce the annual consumption of electricity below $1 \%$. This effect is not desirable compared to the TOU scheme with a $1.4-3.0 \%$ reduction. As noted in the study, the combination of TOU with a block pricing policy performs worse in reducing electricity consumption, probably because the users do not know which price they should respond to and are confused about the nonlinear nature of block pricing [50].

The authors of [51] presented a simulation model of buildings in Ireland that allowed them to calculate the effectiveness of DR programs based on rules and machine-learning algorithms (predictive algorithms), applying different TOU rates. The results indicated that it is possible to obtain reductions in end-use electricity expenditure, utility generation costs, and carbon emissions, with proportions close to $20 \%$ in the rule-based algorithm and $40 \%$ in the predictive algorithm. 


\section{Critical Peak Pricing (CPP)}

Critical peak pricing is a dynamic way of applying prices via a TOU scheme when shortage conditions are detected in the electrical system. In this case, users have to pay higher prices if there is no generation or if events disconnect grid elements [52]. As indicated above, CPP is a variant of the TOU scheme that expresses the volatility of peak prices in the electricity market.

\section{Real-Time Pricing (RTP)}

RTP expresses the prices that result in the WEM at hourly intervals or other lengths of time established by the regulations, exposing the user to the variability that represents the real costs of supplying to utility providers and other consumers [11]. The study in [53] proposes a novel methodology that combines real-time pricing with real-time incentives.

\section{Peak Time Rebate (PTR)}

According to the authors of [54], PTR programs recognize users with monetary discounts that respond to a reduction in electricity consumption during peak hours, because the highest costs are reached in this block of hours. Consumers who do not display this flexibility pay the standard tariff. For this reason, PTR programs typically see much higher participation rates than many other DR programs. In addition, PTR programs have high customer satisfaction ratings, and on the utility side, PTR programs do not require any changes in rate design. PTR programs can benefit both customers and utility providers, resulting in a win-win outcome if PTR rebate levels are set correctly.

\subsubsection{Incentive-Based DR}

In literature reports, incentive-based programs are classified into classical and marketbased programs. In the first group, participants receive credit or a discount during the billing process for reducing their consumption. In the second group, participating users receive a reward proportional to the change in their electricity consumption during the peak hour block [55]. The purpose of incentive-based programs is to flatten the daily load curve by taking advantage of market price variations. The demand reduction contracts are signed and activated when the market exhibits high prices or the system operator understands that reliability is compromised [7].

The reliability of an electrical system can be evaluated over time through the dimensions of security, firmness, adequacy, and strategic planning. DR programs contribute to the reliability of capacity, frequency-regulation reserves, and energy from the perspective of the service and the incentives involved. Additionally, flexibility and contingency could be categorized as special reserve markets for frequency regulation. In the case of a flexibility service, an additional load is required following significant unforecasted wind or solar ramps, and a contingency service responds rapidly to a loss in supply energy [56]. A description of service attribute areas is given in [11]. Below is a brief review:

\section{Capacity}

This service offers a displacement of traditional generation, motivating the controlled dispatch of load through DR programs. The required balance between generation and demand is preserved since an increased load in a bus of the system is offset by the decreased load committed in the DR program in another bus, without dispatching additional megawatts of generation. The participation of DR in capacity markets can combat the increase in capacity prices, mitigating the challenge of integrating high levels of renewables [57], strengthening supply security, and reducing residual loads in the peak period [58]. There are several metrics for measuring this resource. Among them are cited the loss of load probability (LOLP), the loss of load expectation (LOLE), and the expected unserved energy (EUE). 


\section{Frequency-Regulation Reserve}

The effect of DR reserves is the same as synchronized spinning reserves, since they can be activated automatically in a very short time, during the first seconds or minutes after a failure. A frequency-regulation reserve provides the response required to balance generation and demand after a contingency event for a transmission failure or the loss of a generation unit [59]. In the case of non-spinning and non-synchronized operating reserves, the actuation time can also be adjusted to use DR reserves according to the necessities of the system's stability [60].

\section{Emergency}

From the operational planning perspective, the generation needs can be complemented with the energy balance of DR programs, facilitating the optimization of the process, especially in emergency situations or shortages due to the lack of the reliability of generation units [61]. A pilot study of this scheme is evaluated in [62].

\section{Performance Indicators of Demand-Response Programs in Wholesale Electricity Markets}

It is necessary to identify indicators to assess the performance of electricity markets; deciding which are directly related to the market being analyzed will favor the quality of the process assessment and the proposed decisions. Some authors present the following calculations as key performance indicators to respond to and evaluate market behavior: wholesale generation costs, acquisition costs of reserved generation capacity, environmental impact measured by the costs associated with $\mathrm{CO}_{2}$ emissions minus the costs avoided by the reduction of $\mathrm{SO}_{2}$ and $\mathrm{NO}_{\mathrm{X}}$ emissions, reduction of peak prices, lost renewable energy, valuation of unserved energy, percentage of renewable generation, and imported net energy [63].

Several works describe the energy market based on performance indicators. In $[64,65]$, the generation costs are associated with $\mathrm{CO}_{2}$ emissions, the use of primary energy, the load factor of the generators, and the number of hours for which it is possible to disconnect the thermal generators to meet the demand for energy with renewables. In these cases, demand management is expected to influence the efficient operation of electricity generation and the increase in the implementation of RESs to meet the energy demand.

The future poses the challenges of generating electricity with low carbon emissions and providing greater access to energy. For this reason, it is necessary to include objectives related to social and environmental concerns in energy system design [66].

The use of storage systems helps increase the participation of renewable energies in the coverage of demand and the use of available intermittent resources [67]. From the perspective of demand, the influence of the availability of renewable energy in distributed storage systems will guide decision-making in managing the electricity market [68].

Other authors have shown that integrating different energy sources is essential for energy management through intelligent systems [69] and increasing the implementation of renewables, thus reducing the instability of the quality parameters of the electricity supply. In this sense, it is necessary to identify indicators that allow the valuation of market scenarios.

- Key Performance Indicators related to DR

In energy-use management, DR has become a valuable mechanism that impacts costs, the environment, and the well-being of society; however, there are challenges to exploiting its potential, considering the technological and contextual diversity of its application by users and utility providers. The following Key Performance Indicators (KPIs) are used by the authors of [70] to assess the applicability of DR programs: Percentage of variations in electricity load during the peak hour block, percentage of variations in electricity load during the off-peak hour block, percentage ratio of unserved energy from baseline consumption, percentage of consumer participation, and percentage of consumer response. 
In [71], the energy intensity of the industrial sector was related to the flexibility of load per inhabitant and was used as a successful indicator of DR implementation. The study verified that the number of energy-intensive industries is directly related to the potential for the deployment of DR. According to the authors of [18], in Malaysia, the intensity of electricity consumption increased favorably by $8.5 \%$ according to the gross domestic product due to the appropriate planning of the energy balance.

For the use of public funds, specifically in subsidies, a model can be used where the DR's deployment level is established as a parameter [72]. This task involves the analysis of the electricity consumption and the required tariff structure to determine the will and the payment capacity of the population.

The authors of [73] classified KPIs according to social, economic, technical, environmental, and legal concerns from the stakeholder perspective. In the group of technical KPIs related to DR in the WEM, they proposed: Percentage implementation of renewables to meet thermal generation needs, percentage of energy resources distributed in the generation mix, reduction percentage of peak plants based on the ratio of renewable energy to total energy, and average interruption frequency and average interruption duration.

- The elasticity of the demand

The elasticity of demand measures the sensitivity or responsiveness experienced by the quantity demanded when there is a percentage change in its price. Based on this simple definition, the elastic behavior of consumer demand indicates that minor variations in prices produce significant variations in the quantity demanded.

In WEMs, the participation of active demand directly affects prices and generation dispatch. This participation can be understood as a DR when it presents an elastic condition, especially in periods of high prices. The work carried out by the authors of [74] simulates the impact of demand price elasticity in programs based on real-time pricing (RTP) and peak-time rebate (PTR). Other works that have modeled demand price elasticity in the market can also be consulted [75-80]. Equation (1) represents the price elasticity of demand $(\varepsilon)$ and is explained in [81].

$$
\varepsilon=\frac{\Delta \% D}{\Delta \% P}=\frac{\frac{\Delta D}{D}}{\frac{\Delta P}{P}}=\frac{\frac{\left(D_{1}-D_{0}\right)}{D_{0}}}{\frac{\left(P_{1}-P_{0}\right)}{P_{0}}}=\frac{\left(D_{1}-D_{0}\right)}{\left(P_{1}-P_{0}\right)} \times \frac{P_{0}}{D_{0}}
$$

where $\varepsilon=$ the price elasticity of demand; $D_{1}=$ the quantity of demand $1 ; D_{0}=$ the quantity of demand $0 ; P_{1}=$ the price of demand 1 ; and $P_{0}=$ the price of demand 0 .

In [82], the behavior of price elasticity is compared across a time horizon, showing a more significant price in the long term. Consequently, electricity users are more sensitive to price and policy changes in the long term, while in the short term, price policy may have a moderate impact, according to the investigations into residential customers.

\section{- Constant elasticity of substitution}

The elasticity of substitution indicates the level of sensitivity that the relationship between two production or utility function factors displays when the marginal rate of its products or profits varies. It measures the curvature of an isoquant, or a curve of indifference, and the possibility of substituting factors or goods.

In [83], the substitution elasticity constant was used to develop a DR program application model derived from a time-based tariff. Unlike DR models based on price elasticity, the proposed model evaluated a continuous decision-making process, allowing greater flexibility. Another model of elasticity of substitution, which considers the DR during peak and valley periods, is explained in [84], based on an incentive scheme that allows profit maximization for an electricity retailer.

Usually, models use the price elasticity of demand, assuming that the consumer behavior at a particular point of the demand curve is like any other. They linearize the demand curve with a present value of the price elasticity, motivating assumptions that produce discontinuities in the decision-making process [83]. The appropriate treatment 
is to overcome the elasticity of substitution instead of the price elasticity of demand. The substitution elasticity function for two products $\left(X_{1}, X_{2}\right)$ is presented in Equation (2):

$$
U\left(X_{1}, X_{2}\right)=\gamma\left(\alpha X_{1}^{-\rho}+(1-\alpha) X_{2}^{-\rho}\right)^{-\frac{\vartheta}{\rho}}
$$

where $\gamma=$ the efficiency parameter; $\alpha=$ the intensity factor of good $X_{1} ;(1-\alpha)=$ the intensity factor of good $X_{2} ; \vartheta=$ the degree of scale; and $\rho=$ the substitution parameter.

The utility function corresponding to the constant elasticity of substitution (CES) is prevalent in applications that include multiproduct scenarios in microeconomics [83].

The application of this function in the electricity market assumes that the energy supply is different for each period, motivating different prices in the consumer profile. In this case, the coefficient of elasticity of substitution can be determined from the expression $(1-\rho)^{-1}$. The elasticity substitution constant is usually applied to evaluate integrated general equilibrium models [85].

The authors of [85] indicate that the flexibility of substituting demand in quantity and time can define the evaluation criteria for DR programs. Therefore, the elasticity of substitution parameter is essential to determine the benefits of DR programs and to define whether they are implemented according to the objective function of reducing the costs of the electricity supply, considering the ability of users to reschedule their consumption routines for different periods if given an incentive of reduced prices or other income.

\section{Methodologies Used to Model Demand-Response and Sustainability Dimensions}

Some authors have considered models for integrating decision variables to manage an adequate DR due to the flexibility conditions that it represents in the context of the planning and operation of the system and the electricity market. Technical, economic, social, and environmental parameters are considered for decision-making assistance, even if they are dispersed, due to the complexity of the electricity sector. Optimization tools are used to respond to these requirements, such as EFOM, OREM, GAMS, HOMER, EnergyPLAN, ED, OseMOSYS, PLEXOS, MESSAGE, MARKAL, TIMES, LEAP, and MATLAB [86-92].

- Methodologies used to model DR

In the literature, models for decision-making combine different technical aspects and scenarios with RESs to evaluate DR programs in WEMs, microgrids, or DNs.

According to the authors of [93], the models that consider the integration of renewables and the implementation of flexible resources, such as storage and DR, can be classified into three general categories: optimization, partial or total equilibrium, and alternative models. In the first case, continuous, integer, and stochastic programming techniques are applied. In the second case, optimizations include functions that evaluate cost minimization. In the last category, models of probabilistic order, life-cycle evaluation, econometrics, and the modern theory of portfolio management are incorporated. In recent years, the perspective of Stackelberg has been analyzed as a case of game theory and used to model problems in the context of the smart grid [94]. This classification of related works has been reviewed and summarized in Table 1, where DR is demand response, RESs are renewable energy sources, WEM is wholesale electricity market, DN is distribution network, MG is microgrid, $\mathrm{EV}$ is electric vehicle, and ES is energy storage. 
Table 1. Characterization of methodologies for modeling demand response

\begin{tabular}{|c|c|c|c|c|c|c|c|}
\hline Case & Model & Software Tools & Objective & Criteria & Contribution & Limitation & Reference \\
\hline $\mathrm{DR}+\mathrm{RES}$ & Energy-planning model & TIMES & $\begin{array}{l}\text { Minimizing cost through } \\
\text { long-term planning }\end{array}$ & $\begin{array}{l}\text { Maintaining a given level } \\
\text { of reliability }\end{array}$ & $\begin{array}{l}\text { Increasing the implementation } \\
\text { of intermittent renewable } \\
\text { energies reduces the reliability } \\
\text { of the supply, meaning the DR } \\
\text { resource can be considered to } \\
\text { guarantee the required balance } \\
\text { between generation and } \\
\text { electrical load. }\end{array}$ & $\begin{array}{l}\text { For this long-term planning } \\
\text { approach, it is suggested that the } \\
\text { reliability assessment should } \\
\text { concentrate on the sufficiency } \\
\text { aspects related to the capacity and } \\
\text { investment in renewable sources. } \\
\text { The variability experienced by } \\
\text { renewable sources and its impact } \\
\text { on the balance between } \\
\text { generation and demand can be } \\
\text { more rigorously evaluated in a } \\
\text { short-term scope. }\end{array}$ & [95] \\
\hline $\mathrm{DR}+\mathrm{MG}+\mathrm{EV}+\mathrm{ES}$ & Load-scheduling model & ANYLOGIC & $\begin{array}{l}\text { Minimizing cost } \\
\text { through residential } \\
\text { microgrid devices }\end{array}$ & Flexibility aggregator & $\begin{array}{l}\text { The flexible resources with the } \\
\text { most potential to provide the } \\
\text { renewable generation portfolio } \\
\text { of an aggregator are } \\
\text { concentrated in residential } \\
\text { demand, with the participation } \\
\text { of EVs, batteries, and heaters. }\end{array}$ & $\begin{array}{l}\text { It is pertinent to incorporate } \\
\text { scenarios that can simulate } \\
\text { air-conditioning equipment, } \\
\text { considering that it is an important } \\
\text { consumption component in the } \\
\text { cost of electricity for residential } \\
\text { users in some countries. }\end{array}$ & [96] \\
\hline $\mathrm{DR}+\mathrm{WEM}$ & $\begin{array}{l}\text { A two-stage stochastic } \\
\text { model incorporating } \\
\text { game theory }\end{array}$ & GAMS/CPLEX & $\begin{array}{l}\text { Minimizing total } \\
\text { operational cost using } \\
\text { Security-Constrained } \\
\text { Unit Commitment }\end{array}$ & Oligopolistic environment & $\begin{array}{l}\text { Results reveal that DR } \\
\text { programs affect oligopoly } \\
\text { activities in the market in the } \\
\text { presence of renewable } \\
\text { energy resources. }\end{array}$ & $\begin{array}{l}\text { Operational flexibility is of greater } \\
\text { importance as the implementation } \\
\text { of variable renewables increases. } \\
\text { Therefore, the study can be } \\
\text { complemented by incorporating } \\
\text { flexible resources, such as } \\
\text { battery storage. }\end{array}$ & [97] \\
\hline $\mathrm{DR}+\mathrm{EV}+\mathrm{ES}$ & $\begin{array}{l}\text { A two-stage } \\
\text { stochastic model }\end{array}$ & GAMS/CPLEX & $\begin{array}{l}\text { Maximizing total expected } \\
\text { profits of domestic energy }\end{array}$ & $\begin{array}{l}\text { Smart-home modeled like } \\
\text { a price taker }\end{array}$ & $\begin{array}{l}\text { The TOU pricing scheme } \\
\text { benefits the market due to its } \\
\text { contribution to reducing } \\
\text { operating costs and increasing } \\
\text { the smart-home } \\
\text { user's profitability }\end{array}$ & $\begin{array}{l}\text { The domestic load scheduling that } \\
\text { minimizes energy consumption, } \\
\text { considering the comfort } \\
\text { preferences of the participating } \\
\text { users, may imply an extra cost for } \\
\text { the operation of the wholesale } \\
\text { electricity market because higher } \\
\text { levels of the reserve may be } \\
\text { required for the provision of the } \\
\text { regulation service frequency } \\
\text { under conditions of } \\
\text { demand uncertainties. }\end{array}$ & [68] \\
\hline
\end{tabular}


Table 1. Cont.

\begin{tabular}{|c|c|c|c|c|c|c|c|}
\hline Case & Model & Software Tools & Objective & Criteria & Contribution & Limitation & Reference \\
\hline DR + Carbon Scenarios & Long-term model & OSeMOSYS & $\begin{array}{l}\text { Minimizing cost of } \\
\text { operation and total } \\
\text { installed capacity }\end{array}$ & Planning operation & $\begin{array}{l}\text { The assessment of DR } \\
\text { implementation could be } \\
\text { verified by reducing the cost of } \\
\text { operation and total installed } \\
\text { capacity significantly when the } \\
\text { renewable capacity and } \\
\text { generation increase. }\end{array}$ & $\begin{array}{l}\text { The application of this study } \\
\text { should be extended to the case of } \\
\text { electrical systems in island } \\
\text { countries, where it is not possible } \\
\text { to take advantage of the } \\
\text { interconnections of electrical } \\
\text { systems in neighboring countries; } \\
\text { a comparison should be made } \\
\text { with the peninsular-base case } \\
\text { of Portugal. }\end{array}$ & [6] \\
\hline $\mathrm{DR}+\mathrm{ES}+\mathrm{RES}$ & Energy-hub model & GAMS/CPLEX & $\begin{array}{l}\text { Minimizing total cost } \\
\text { of energy }\end{array}$ & $\begin{array}{l}\text { Divide complex problem } \\
\text { of energy-hub model into } \\
\text { smaller subproblems }\end{array}$ & $\begin{array}{l}\text { The methodology of dividing } \\
\text { the complex problem of the } \\
\text { energy-hub model allows the } \\
\text { transformation from nonlinear } \\
\text { to linear without the loss of } \\
\text { relevant information. }\end{array}$ & $\begin{array}{l}\text { The prioritization criteria should } \\
\text { be defined according to the } \\
\text { energy source that participates in } \\
\text { the demand-response programs; } \\
\text { the stochastic weighting of the } \\
\text { objectives related to increases in } \\
\text { benefits and user comfort and the } \\
\text { reduction of operating costs in the } \\
\text { markets should also be defined. }\end{array}$ & [98] \\
\hline $\mathrm{DR}+\mathrm{RES}+\mathrm{ES}+\mathrm{MG}$ & $\begin{array}{l}\text { Multiple-year } \\
\text { planning model }\end{array}$ & GAMS/CPLEX & Maximizing social benefits & Integration of RESs and ES. & $\begin{array}{l}\text { Implementing DR with } \\
\text { renewable energy resources and } \\
\text { storage in remote communities } \\
\text { can improve social welfare. }\end{array}$ & $\begin{array}{l}\text { Although some of the users in } \\
\text { these remote communities can } \\
\text { assume a change in their } \\
\text { consumption pattern to reduce } \\
\text { fuel costs, the inclusion of an } \\
\text { incentive scheme can be explored } \\
\text { to motivate greater participation. }\end{array}$ & [99] \\
\hline $\mathrm{DR}+\mathrm{ES}+\mathrm{RES}+\mathrm{MG}$ & $\begin{array}{l}\text { Enhanced rural } \\
\text { electrification model }\end{array}$ & HOMER & $\begin{array}{l}\text { Minimizing the levelized } \\
\text { cost of energy, the net } \\
\text { present cost, and the } \\
\text { carbon dioxide } \\
\left(\mathrm{CO}_{2}\right) \text { emissions }\end{array}$ & $\begin{array}{l}\text { Sizing of an integrated } \\
\text { renewable energy system }\end{array}$ & $\begin{array}{l}\text { Combining DR with a level of } \\
\text { participation of renewable } \\
\text { energies reduces the levelized } \\
\text { cost of energy. }\end{array}$ & $\begin{array}{l}\text { The determination of the levelized } \\
\text { cost of energy in this study does } \\
\text { not consider the inconveniences } \\
\text { of the commercial management of } \\
\text { electricity services in rural } \\
\text { communities that are being } \\
\text { electrified. This variable can be } \\
\text { incorporated into the model, } \\
\text { considering that these users must } \\
\text { assume a new commitment and, } \\
\text { therefore, a new habit. }\end{array}$ & [100] \\
\hline $\mathrm{DR}+\mathrm{RES}+\mathrm{WEM}$ & Optimal-dispatch model & MATLAB & $\begin{array}{l}\text { Minimizing the costs of } \\
\text { operation, incentive, and } \\
\text { expected } \\
\text { unsupplied energy }\end{array}$ & Reliability & $\begin{array}{l}\text { The design of a dynamic } \\
\text { incentive mechanism and a new } \\
\text { expected-energy formulation } \\
\text { could determine the conditions } \\
\text { that must be sustained to carry } \\
\text { out the electrical system's } \\
\text { economical and } \\
\text { reliable operation. }\end{array}$ & $\begin{array}{l}\text { The security concept considered } \\
\text { for the short term should be } \\
\text { defined to clarify the reliability } \\
\text { dimension of the model. }\end{array}$ & [101] \\
\hline
\end{tabular}


Table 1. Cont.

\begin{tabular}{|c|c|c|c|c|c|c|c|}
\hline Case & Model & Software Tools & Objective & Criteria & Contribution & Limitation & Reference \\
\hline $\mathrm{DR}+\mathrm{WEM}$ & $\begin{array}{l}\text { DR model based } \\
\text { on incentive }\end{array}$ & MATLAB & $\begin{array}{l}\text { Maximizing retailer } \\
\text { benefits }\end{array}$ & $\begin{array}{l}\text { Utility and } \\
\text { elasticity of customers }\end{array}$ & $\begin{array}{l}\text { The sensitivities of the criteria } \\
\text { of utility and the elasticity of } \\
\text { the customers allow innovation } \\
\text { in determining the optimal } \\
\text { incentive price for each period } \\
\text { in the electricity load curve. }\end{array}$ & $\begin{array}{l}\text { This model explores retailer } \\
\text { maximization derived from an } \\
\text { incentive-based demand-response } \\
\text { program. The model does not } \\
\text { necessarily represent the total net } \\
\text { benefit of all market agents, } \\
\text { motivating the need to determine } \\
\text { if its application minimizes the } \\
\text { operational cost of supply. }\end{array}$ & [84] \\
\hline $\mathrm{DR}+\mathrm{ES}+\mathrm{RES}$ & $\begin{array}{l}\text { DR model based on } \\
\text { interruptible load }\end{array}$ & $\begin{array}{l}\text { Program based on } \\
\text { genetic algorithm }\end{array}$ & $\begin{array}{c}\text { Maximizing } \\
\text { consumer benefits }\end{array}$ & Maximum demand index & $\begin{array}{l}\text { The application of the } \\
\text { interruptible-load model } \\
\text { contributes to the reduction of } \\
\text { invoicing and } \\
\text { customer demand. }\end{array}$ & $\begin{array}{l}\text { The results obtained from the } \\
\text { load-interruption program do not } \\
\text { mean that there would be a } \\
\text { reduction in the maximum } \\
\text { coincident demand of the system, } \\
\text { which motivates the evaluation of } \\
\text { this condition. }\end{array}$ & [102] \\
\hline $\mathrm{DR}+\mathrm{RES}+\mathrm{DN}$ & $\begin{array}{c}\text { DN model based on Nash } \\
\text { equilibrium }\end{array}$ & $\begin{array}{l}\text { TIMES } \\
\text { OSeMOSYS } \\
\text { ETEM-SG }\end{array}$ & $\begin{array}{l}\text { Minimizing grid } \\
\text { operator cost }\end{array}$ & $\begin{array}{l}\text { DER and reactive } \\
\text { power compensation }\end{array}$ & $\begin{array}{l}\text { The implementation levels of } \\
\text { renewable energies favor the } \\
\text { inclusion of DR in distributed } \\
\text { energy markets. }\end{array}$ & $\begin{array}{l}\text { The results should be compared } \\
\text { with other modeling tools, } \\
\text { indicating the conditions required } \\
\text { to be chosen. }\end{array}$ & [103] \\
\hline
\end{tabular}


- $\quad$ Sustainability dimensions in DR models

Energy modeling is a multidimensional concept that is challenging to explain from a single methodological perspective. One of the most frequently used classifications in the literature, dedicated to disaggregating the different dimensions applicable in development models, such as those that incorporate renewable energy and flexible resources in electrical systems, is related to the concept of sustainable development (SD). This conception rests on three fundamental pillars (social, economic, and environmental). It has been a ubiquitous concept since 1987, when it was proposed by the United Nations as a process leading to "development that meets the needs of the present without compromising the ability of future generations to meet their own need" $[104,105]$. The conditions required to maintain the balance between the three components of SD are not easy to achieve, since the goals of each pillar must respect the interests of the remaining pillars [106]. Figure 6 summarizes the taxonomy of SD in a Venn-Euler diagram.

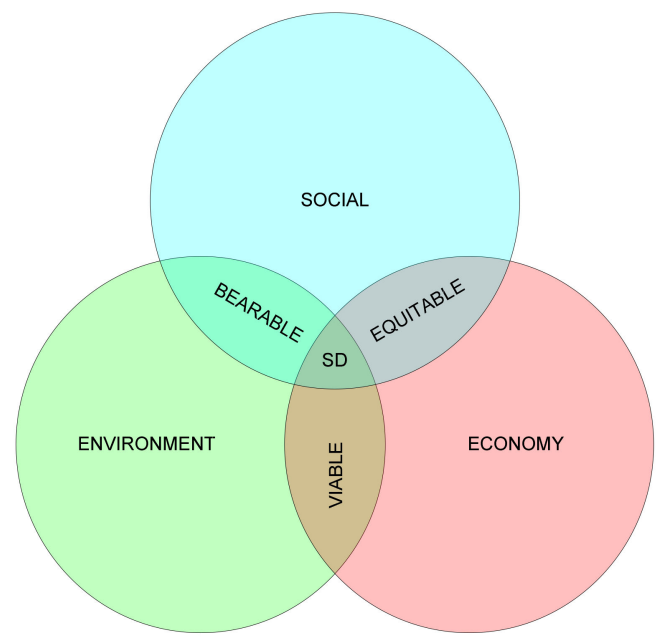

Figure 6. Venn diagram of SD. Adapted from [106]

The analysis of energy demand is a vital part of planning studies for meeting the energy needs of a nation and determining their impact on society, the economy, and the environment $[107,108]$. Table 2 contextualizes the research related to the evaluation of DR and its integration in the planning and operation of electrical systems.

Table 2. Sustainability categories used for assessing demand response.

\begin{tabular}{|c|c|c|c|c|}
\hline \multirow{2}{*}{ Energy Activity Combined with DR } & \multicolumn{2}{|c|}{ Sustainability Category } & \multirow{2}{*}{$\begin{array}{l}\text { From the Objective } \\
\text { Function Perspective }\end{array}$} & \multirow{2}{*}{ Reference Model } \\
\hline & Included & Excluded & & \\
\hline Microgrid + distributed ES devices & Economic & $\begin{array}{l}\text { Environmental, } \\
\text { Social }\end{array}$ & Minimizing total cost of energy. & [109] \\
\hline Wind energy + pump storage & Economic & $\begin{array}{l}\text { Environmental, } \\
\text { Social }\end{array}$ & $\begin{array}{l}\text { Maximizing net profit considering } \\
\text { risk-averse day-ahead bidding. }\end{array}$ & [110] \\
\hline Energy hub & Economic & $\begin{array}{l}\text { Environmental, } \\
\text { Social }\end{array}$ & Minimizing total cost of energy. & [98] \\
\hline $\begin{array}{l}\text { Microgrid + storage + renewable } \\
\text { energy resources }\end{array}$ & $\begin{array}{l}\text { Economic, } \\
\text { Social }\end{array}$ & Environmental & $\begin{array}{l}\text { Maximizing the social benefits of } \\
\text { the customers. }\end{array}$ & [99] \\
\hline Energy flexibility of buildings & $\begin{array}{l}\text { Environmental, } \\
\text { Economic }\end{array}$ & Social & $\begin{array}{l}\text { Price modulation to reduce } \mathrm{CO}_{2} \\
\text { emissions and cost savings. }\end{array}$ & [111] \\
\hline $\begin{array}{l}\text { Microgrid }+ \text { distributed energy } \\
\text { generation }\end{array}$ & $\begin{array}{l}\text { Environmental, } \\
\text { Economic }\end{array}$ & Social & Minimizing total cost of energy. & {$[112]$} \\
\hline Microgrid + storage & $\begin{array}{l}\text { Environmental, } \\
\text { Economic }\end{array}$ & Social & $\begin{array}{l}\text { Minimizing levelized cost of } \\
\text { energy, net present cost, and } \\
\text { carbon dioxide }\left(\mathrm{CO}_{2}\right) \text { emissions. }\end{array}$ & {$[100,113]$} \\
\hline Smart grid & $\begin{array}{l}\text { Environmental, } \\
\text { Economic, social }\end{array}$ & - & $\begin{array}{l}\text { The implementation of the } \\
\text { aggregator figure results to reduce } \\
\mathrm{CO}_{2} \text {, with social and economic } \\
\text { benefits for the customers. }\end{array}$ & [114] \\
\hline
\end{tabular}


Several methodologies for the economic assessment of DR programs differ primarily by the perspective used to analyze the cost-benefit ratio.

- $\quad$ Based on the utility test

This perspective is often referred to as the Program Administrator Cost (PAC) or Utility Cost Test (UCT). This methodology measures the impact on the income company. The benefits included are the avoided transmission costs, including operation and maintenance (OM) costs. These costs have a more significant impact in the case of energy efficiency programs, where there is a net reduction in energy that the company sells to a customer. The energy-saving cost is a helpful metric for program administrators and regulators [115].

- $\quad$ Based on the participant cost test

This method compares bill savings against incremental costs of the efficient equipment [116]. The benefits include incentives received by the customer and reductions in energy bills. This test is a good indicator of how acceptable a DR program would be for customers and therefore helps determine the likelihood of acceptance by clients.

- $\quad$ Based on the total resource cost test

This test measures the benefit-cost ratio from a broader perspective and includes all the costs and benefits of a DR program. Benefits include the avoided costs of transmission, distribution, power generation capacity, and losses. Additionally, it considers OM costs, administrative costs, opportunity costs to reduce losses in networks, and investment resources required in DR programs [115].

- Based on the total societal cost

This test only measures if the total cost is reduced by applying DR programs and, therefore, if the programs are beneficial to society. The other tests measure how the company, participants, and customers distribute the costs and benefits. This methodology compares the costs and benefits for utility providers, customers, and society [117].

\section{Model Scheme Proposed Based on the Literature Review}

The state of the art covered in this research on DR transcends the descriptive level when verifying new possibilities in the WEM. The low number of publications addressing operational flexibility is notable and is partly due to the traditional activities and roles of the different agents that participate in the WEM. With this epistemological support, a methodology is constructed to model DR programs in the market, which considers the concepts of segmentation, the elasticity of substitution, and DR programs, combined with high implementation levels of variable renewable energies. Therefore, several resources are associated with the same operating model.

The complexity of a model grows with the number of variables and restrictions that must be considered to optimize an objective function. The proposed model shows a weekly operation program for an electrical power system that includes a generation mix with the significant participation of variable renewable energy, TNs, and end-users who are willing to receive an incentive for managing the demand with flexibility criteria.

The proposed methodology is based on the following elements: the prospecting of variable renewable energy; the segmentation of consumption profiles according to the elasticity of substitution; a program of DR based on incentives; and the determination of the cost of supply, considering economic, social, and environmental criteria. The novelty of this modeling method focuses on the combination of variable renewable energy prospects and the application of segmentation techniques for consumer user profiles, based on the levels of flexibility adjusted using CES applied to DR programs, which encourage the load-shifting strategy.

In the literature, some criteria have been used to validate the hypothesis that an increase in the level of the participation of variable renewable energies in the WEM produces a reduction in energy prices, especially in the short term. However, the premise 
of reducing prices by increasing renewable generation may be conditioned by flexibility incentives [118]. In [119], several studies are analyzed that evaluate the impact of variable renewable energies in the wholesale generation markets of the United States, highlighting the trend that an average reduction of $-\$ 0.37$ /MWh occurs with a $1 \%$ increase in the implementation of variable renewable energies. These price variation conditions are subject to the specifications of the markets and the electrical systems, such as the generation mix, the ancillary services offered, the safety criteria required in the operation, and the regulatory policies established to minimize the generation dispatch cost and to maximize the net social benefit of the agents in the WEM.

In [76], the authors propose a price-based DR model for residential customers who can change their consumption profile, maximizing profits. Although the model proposal responds to an incentive-based design, it is complemented by the strategy of shifting load between hourly blocks, from peak to valley and from shoulder to valley periods, through a process of iterations.

Additionally, this methodology considers a novel segmentation of demand, supported by statistical criteria and a constant return to scale, ensuring that the budget destined for the payment of energy consumption costs is not affected by increases in the price components of the hourly blocks. The effect of increasing the returns to scale of the CES function is shown in [120], demonstrating consistency with the average and marginal profits under conditions approaching the limits of the production factors.

Most of the mechanisms analyzed based on the CES function correspond to long-term programs due to the essence of the macroeconomic problems of production and profits, as deduced in [121-126]. This has led to a gap in the research exploring the behavior of the WEM in short-term applications, which is addresses in our methodology.

As shown in Figure 7, this methodology is supported in a multiobjective iterative process, in which the cost of supplying a base scenario is minimized without the participation of DR programs. The load-shifting error based on coefficients that represent the elasticity of substitution between periods and the cost of applying for an active and flexible DR program with an increasing level of renewable energy in the WEM motivate the determination of the cost of supply in these new conditions and their comparison with the results of the baseline scenario.

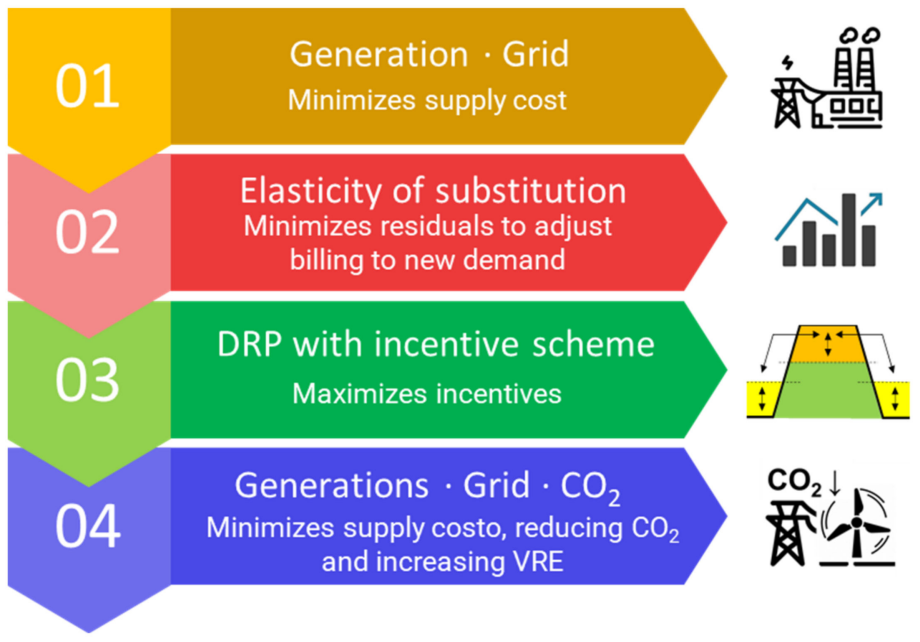

Figure 7. Sequential modeling scheme.

The dimensioning of the model was expressed through a modular separation of the entire process, simplifying the optimization problem. This work scheme facilitates the analysis of results and the identification or anticipation of possible difficulties.

The proposed methodology operates in a sequential form, based on a generation model for performing an economic operation dispatch and guaranteeing the minimization of the supply cost. The demand parameters used will be managed in a base scenario 
that includes all demand. In an adjusted final case, part four of the sequential model, the cost of $\mathrm{CO}_{2}$ emissions and the segmentation of the flexible load profiles, defined by the elasticity of substitution model, are considered to apply the strategy of shifting demand from the peak periods of the daily load curve to the valley and shoulder periods. In this case, demand in the WEM is concentrated in large/industrial consumers and the figure of the retailing agent.

Usually, large/industrial consumers have the advantage of negotiating prices under unregulated conditions in the WEM. The participation of residential and commercial users is more complicated, considering that they cannot establish significant modifications in the records. The aggregators verify the consumption profiles, offering DR programs based on participation options that guarantee market incentives. Therefore, it is justified that utility providers and end-users study the different consumer segments based on characteristics that allow the management of previously identified user clusters.

The structure of the model takes into account concepts such as economic dispatch, as developed by [90]; the treatment of renewable generation and demand response according to [83,127-129]; the coefficient of elasticity of substitution (CES) outlined by [130]; and $\mathrm{CO}_{2}$ emission control described by [131], associated with the methodology of the Intergovernmental Panel on Climate Change (IPCC), used to quantify $\mathrm{CO}_{2}$ emissions at three levels of detail. The main modeling specifications for the proposed methodology are shown in Table 3. The details of the restrictions are not contemplated in this work; however, they should be considered during the development of the optimization program to delimit ranges, ramps, reserves, and other aspects of the operation that respond to the topological particularities of the network, the generation plants, the demand, and the market rules.

Table 3. Main modeling specifications.

\begin{tabular}{|c|c|c|c|c|c|}
\hline Stage & $\begin{array}{c}\text { Concept } \\
\text { Description }\end{array}$ & Module 0 & Module 1 & Module 2 & Module 3 \\
\hline Input & Data & $\begin{array}{l}\text { Start-up cost, } \\
\text { shutdown cost, } \\
\text { variable production } \\
\text { cost, the value of } \\
\text { lost load, water } \\
\text { value, demand, } \\
\text { spinning reserve, } \\
\text { technical characteristic } \\
\text { of generation, } \\
\text { and network }\end{array}$ & $\begin{array}{l}\text { Hourly demand } \\
\text { and demand } \\
\text { grouped by blocks, } \\
\text { participants in } \\
\text { DRP, parameters in } \\
\text { CES function, } \\
\text { cs marginal costs }\end{array}$ & $\begin{array}{l}\text { Hourly demand and } \\
\text { demand grouped by } \\
\text { blocks, technical } \\
\text { characteristics of } \\
\text { demand, scenarios of } \\
\text { demand probabilities }\end{array}$ & $\begin{array}{l}\text { Includes data from } \\
\text { modules } 0 \text { and } 2, \\
\text { parameters for } \mathrm{CO}_{2} \\
\text { emission control }\end{array}$ \\
\hline \multirow[t]{3}{*}{ Process } & Decision variables & $\begin{array}{l}\text { Energy generation, } \\
\text { demand pumping, } \\
\text { unserved energy }\end{array}$ & $\begin{array}{l}\text { Residuals from the } \\
\text { CES function }\end{array}$ & $\begin{array}{c}\text { Energy demand } \\
\text { adjusted by DRP, the } \\
\text { incentive for } \\
\text { participants in DRP }\end{array}$ & $\begin{array}{l}\text { Energy generation, } \\
\text { demand pumping, } \\
\text { unserved energy, } \\
\text { emissions of } \mathrm{CO}_{2}\end{array}$ \\
\hline & Objective function & $\begin{array}{l}\text { Minimizing } \\
\text { operation cost }\end{array}$ & $\begin{array}{l}\text { Minimizing } \\
\text { residuals from the } \\
\text { approximate } \\
\text { CES function }\end{array}$ & $\begin{array}{l}\text { Maximizing } \\
\text { incentive scheme }\end{array}$ & $\begin{array}{c}\text { Minimizing operating } \\
\text { cost, including } \\
\text { emissions of } \mathrm{CO}_{2}\end{array}$ \\
\hline & Model type & MIP & NLP & NLP & MIP \\
\hline Output & Main results & $\begin{array}{c}\text { Operating cost, } \\
\text { power and reserve } \\
\text { outputs of } \\
\text { each generator, } \\
\text { marginal costs }\end{array}$ & $\begin{array}{c}\text { New demand } \\
\text { blocks }\end{array}$ & $\begin{array}{l}\text { New hourly demand, } \\
\text { the incentive for } \\
\text { participants in DRP }\end{array}$ & $\begin{array}{l}\text { Operating cost, power } \\
\text { and reserve outputs of } \\
\text { each generator, } \\
\text { marginal costs, } \mathrm{CO}_{2} \\
\text { emissions, profit, and } \\
\text { KPIs to evaluate DRP }\end{array}$ \\
\hline
\end{tabular}

Table 4 summarizes some works that model energy management based on the elasticity of substitution constant, taken as a parameter for developing the methodology proposed in 
this research. The following criteria have been identified for comparative purposes: loadchange profile, energy technology change, variable renewable energy, and $\mathrm{CO}_{2}$ emissions.

Table 4. Summary of energy management proposals based on CES function.

\begin{tabular}{|c|c|c|c|c|c|c|}
\hline \multirow[b]{2}{*}{ Reference } & \multirow[b]{2}{*}{ Main Objective } & \multicolumn{5}{|c|}{ Highlighted Concepts for Comparative Purposes } \\
\hline & & $\begin{array}{c}\text { CES } \\
\text { Function }\end{array}$ & $\begin{array}{c}\text { Load-Shifting } \\
\text { Profile }\end{array}$ & $\begin{array}{c}\text { Energy } \\
\text { Technology } \\
\text { Change }\end{array}$ & $\begin{array}{c}\text { Variable } \\
\text { Renewable } \\
\text { Energy }\end{array}$ & $\underset{\text { Emissions }}{\mathrm{CO}_{2}}$ \\
\hline [132] & $\begin{array}{l}\text { Determine investment in } \\
\text { renewables and storage to } \\
\text { expand the electric } \\
\text { power system. }\end{array}$ & $\mathrm{x}$ & & & $\mathrm{x}$ & \\
\hline [133] & $\begin{array}{l}\text { Analyze the response of } \\
\text { consumers with different } \\
\text { incomes, according to changes } \\
\text { in carbon allowance prices, in } \\
\text { the long and short term. }\end{array}$ & $\mathrm{x}$ & & & & $\mathrm{x}$ \\
\hline [134] & $\begin{array}{l}\text { Develop a methodology to } \\
\text { determine the technological } \\
\text { change from capital, labor, } \\
\text { and energy. }\end{array}$ & $\mathrm{x}$ & & $\mathrm{x}$ & & \\
\hline [135] & $\begin{array}{l}\text { Manage industrial loads from } \\
\text { a demand-response program } \\
\text { based on real-time pricing, } \\
\text { considering adaptability and } \\
\text { adjustability criteria. }\end{array}$ & $\mathrm{x}$ & $\mathrm{x}$ & & & \\
\hline [136] & $\begin{array}{l}\text { Describe the main aspects of } \\
\text { the econometric specification } \\
\text { of the CES function for capital, } \\
\text { labor, and energy inputs. }\end{array}$ & $\mathrm{x}$ & & $\mathrm{x}$ & & \\
\hline
\end{tabular}

The main contribution of the proposed methodology is focused on assessing the performance of DR programs from the perspective of the WEM. The causes of operational inflexibility in generation dispatch are highlighted due to possible increases in marginal energy costs, grid congestion, and insufficient power at peak hours. These issues are characterized by unserved energy scenarios, poor electricity service quality, and the need to intervene through subsidies, as described in Figure 8. It is necessary to have specialized tools to evaluate these cases, as indicated in the structure of this proposal, in order to facilitate decision-making in the activities, institutions, and government agencies related to the electricity sector.

According to [137], the future of renewables cannot exclude DR, considering their contribution to reducing investments in on-peak generation technology and battery storage. The expected results of this research can provide the baseline information to open a discussion on regulatory, economic, social, and environmental issues in terms of:

- Control deviations in the operation of electrical systems.

- The characterization of DR programs according to the elasticity of substitution of participating flexible consumer segments.

- Model validation based on the planning and operational methodology proposed. 


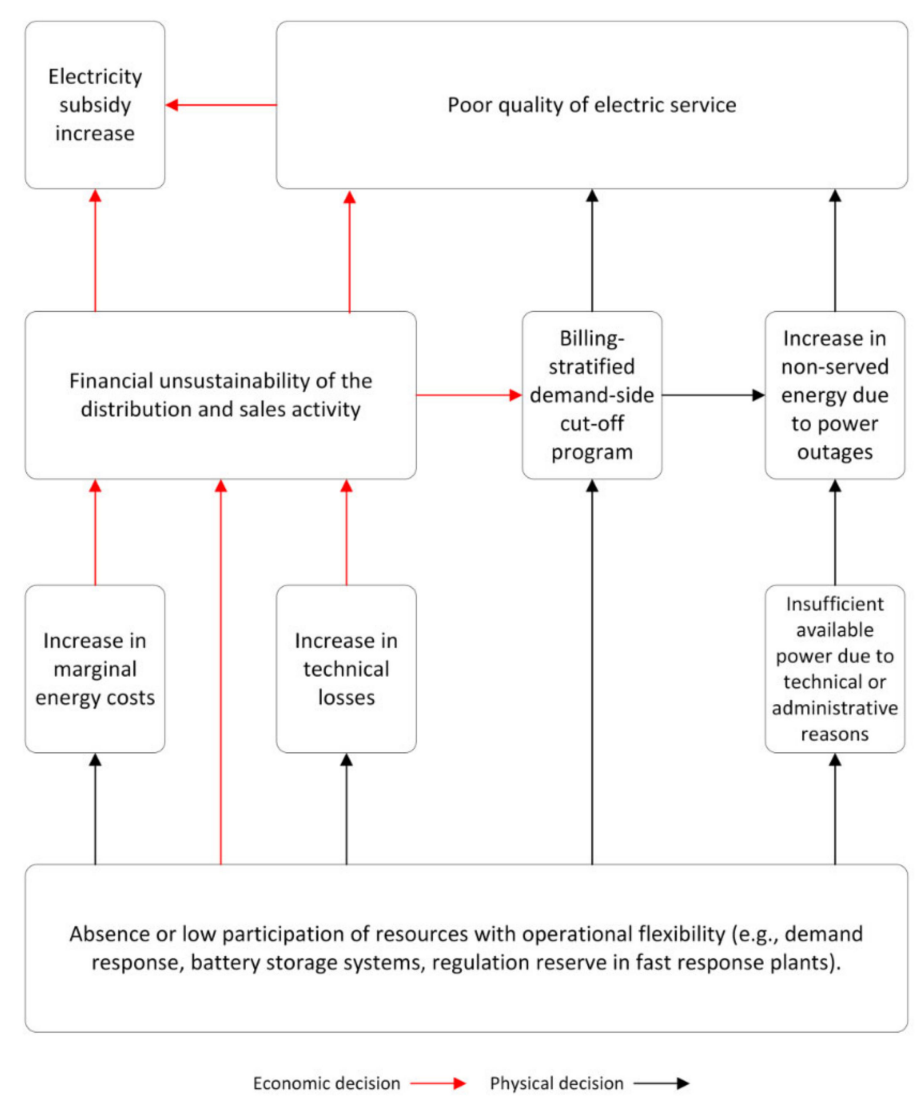

Figure 8. Causes of operational inflexibility and effects on WEM.

\section{Conclusions}

This work provides an overview of the conceptual literature used to plan, model, and evaluate DR programs in the WEM. This paper explains different strategies for changing load profiles. Additionally, it describes the DR programs and the methodologies used to implement these resources in electricity supply operations.

In its main section, this paper presents a methodology for optimizing energy dispatch that considers a demand-shifting strategy supported by an incentive scheme based on demand-segmentation characteristics, utility functions in the elasticity of substitution coefficients, and extensive use of non-conventional renewable energy.

Therefore, this proposed market mechanism, supported by demand-response programs, can be evaluated as providing viable alternatives to improve the quality of service and mitigate subsidy programs. This paper presents an approach to integrating demandresponse programs based on load shifting and increasing variable renewable energy implementation in the wholesale electricity market. The main contributions of the methodology based on the literature review can be summarized as follows:

1. Strategic demand shifts are proposed, focused on taking advantage of the availability of renewable resources and the budgetary restrictions established based on the elasticity of substitution. The methodology takes into account the context of the scheduled operation of the electric system, the need to consider safety criteria, and the limitations of the generation and transmission network.

2. The methodology facilitates the construction of a simulation tool to evaluate scenarios that minimize operating costs, guaranteeing the incentives of flexible demand and mitigating possible deviations in the scheduling of the operation of the electricity system, avoiding cost overruns caused by the forced operation of generation plants.

3. The performance indicators are used to define a method of sensitivity analysis to aid the decision-making process by determining the percentages of demand-shift on the load curve, the rate of unserved power, the incentives of consumers participating in 
demand-response programs, the natural behavior of prices in the market, and the reduction of $\mathrm{CO}_{2}$ emissions.

Finally, it is important to highlight that the proposed methodology is not a tool to minimize costs or reduce $\mathrm{CO}_{2}$ emissions for all cases. The optimization problem's solution depends on the electrical system's generation mix and the technologies used to compensate for the fluctuations.

The future development of this research will contemplate the forecasting of variable renewables, flexible demand segmentation, and the definition of a mechanism to recognize the firm capacity contribution of variable renewable technologies and their remuneration, providing greater availability when complemented by demand-response programs during generation shortage hours in the daily load curve.

Author Contributions: Conceptualization, M.A.D.-G. and A.A.-M.; methodology, M.A.D.-G.; investigation, M.A.D.-G.; writing-original draft preparation, M.A.D.-G.; writing-review and editing, M.A.D.-G., A.A.-M. and M.A.-M.; supervision, V.S.O.-G. and F.S.-G. All authors have read and agreed to the published version of the manuscript.

Funding: This research received no external funding.

Institutional Review Board Statement: Not applicable.

Informed Consent Statement: Not applicable.

Data Availability Statement: Not applicable.

Acknowledgments: The authors would like to acknowledge OC (Organismo Coordinador del Sistema Eléctrico Nacional Interconectado), a nonprofit organization which plays the role of the operator of the wholesale electricity market in the Dominican Republic. The OC provided the invaluable support of specialists to review the proposed methodology.

Conflicts of Interest: The authors declare no conflict of interest.

$\begin{array}{ll}\text { Abbreviations } \\ \text { CES } & \text { Constant Elasticity of Substitution } \\ \text { CPP } & \text { Critical Peak Pricing } \\ \text { DDSM } & \text { Dynamic Demand-Side Management } \\ \text { DLC } & \text { Direct Load Control } \\ \text { DNs } & \text { Distribution Networks } \\ \text { DR } & \text { Demand Response } \\ \text { DSI } & \text { Demand-Side Integration } \\ \text { DSM } & \text { Demand-Side Management } \\ \text { DRP } & \text { Demand-Response Program } \\ \text { ES } & \text { Energy Storage } \\ \text { EUE } & \text { Expected Unserved Energy } \\ \text { EVs } & \text { Electric Vehicles } \\ \text { HVAC } & \text { Heating, Ventilation, and Air Conditioning } \\ \text { IPCC } & \text { Intergovernmental Panel on Climate Change } \\ \text { KPIs } & \text { Key Performance Indicators } \\ \text { LOLE } & \text { Loss-Of-Load Expectation } \\ \text { LOLP } & \text { Loss-Of-Load Probability } \\ \text { NCRE } & \text { Non-Conventional Renewable Energy } \\ \text { O\&M } & \text { Operation and Maintenance } \\ \text { PAC } & \text { Program Administrator Cost } \\ \text { PTR } & \text { Peak Time Rebate } \\ \text { RESs } & \text { Renewable Energy Sources } \\ & \end{array}$




$\begin{array}{ll}\text { RTP } & \text { Real-Time Pricing } \\ \text { SD } & \text { Sustainable Development } \\ \text { SDSM } & \text { Static Demand-Side Management } \\ \text { TNs } & \text { Transmission Networks } \\ \text { TOU } & \text { Time-Of-Use Pricing } \\ \text { UCT } & \text { Utility Cost Test } \\ \text { WEM } & \text { Wholesale Electricity Market }\end{array}$

\section{References}

1. NERC. Demand Response Availability Report; NERC: Atlanta, GA, USA, 2013; Available online: https://www.nerc.com (accessed on 20 August 2021).

2. $\quad$ Paterakis, N.G.; Erdinç, O.; Catalão, J.P.S. An overview of Demand Response: Key-elements and international experience. Renew. Sustain. Energy Rev. 2017, 69, 871-891. [CrossRef]

3. Wang, F.; Xu, H.; Xu, T.; Li, K.; Shafie-Khah, M.; Catalão, J.P.S. The values of market-based demand response on improving power system reliability under extreme circumstances. Appl. Energy 2017, 193, 220-231. [CrossRef]

4. Meyabadi, A.F.; Deihimi, M.H. A review of demand-side management: Reconsidering theoretical framework. Renew. Sustain. Energy Rev. 2017, 80, 367-379. [CrossRef]

5. Wohlfarth, K.; Klingler, A.-L.; Eichhammer, W. The flexibility deployment of the service sector-A demand response modelling approach coupled with evidence from a market research survey. Energy Strategy Rev. 2020, 28, 100460. [CrossRef]

6. Anjo, J.; Neves, D.; Silva, C.; Shivakumar, A.; Howells, M. Modeling the long-term impact of demand response in energy planning: The Portuguese electric system case study. Energy 2018, 165, 456-468. [CrossRef]

7. Lopes, F.; Coelho, H. Electricity Markets with Increasing Levels of Renewable Generation: Structure, Operation, Agent-Based Simulation, and Emerging Designs; Springer: Berlin/Heidelberg, Germany, 2018; Volume 144.

8. Vázquez-Canteli, J.R.; Nagy, Z. Reinforcement learning for demand response: A review of algorithms and modeling techniques. Appl. Energy 2019, 235, 1072-1089. [CrossRef]

9. Zhou, S.; Shu, Z.; Gao, Y.; Gooi, H.B.; Chen, S.; Tan, K. Demand response program in Singapore's wholesale electricity market. Electr. Power Syst. Res. 2017, 142, 279-289. [CrossRef]

10. Patnam, B.S.K.; Pindoriya, N.M. Demand response in consumer-Centric electricity market: Mathematical models and optimization problems. Electr. Power Syst. Res. 2021, 193, 106923. [CrossRef]

11. Gagne, D.A.; Settle, D.E.; Aznar, A.Y.; Bracho, R. Demand Response Compensation Methodologies: Case Studies for Mexico. Available online: https:/ / www.osti.gov/biblio/1452706 (accessed on 20 July 2021).

12. Huang, Y.; Pardalos, P.M.; Zheng, Q.P. Electrical Power Unit Commitment: Deterministic and Two-Stage Stochastic Programming Models and Algorithms; Springer: Berlin/Heidelberg, Germany, 2017.

13. Dadashi, M.; Zare, K.; Seyedi, H.; Shafie-khah, M. Coordination of wind power producers with an energy storage system for the optimal participation in wholesale electricity markets. Int. J. Electr. Power Energy Syst. 2022, 136, 107672. [CrossRef]

14. Dranka, G.; Ferreira, P. Review and Assessment of the Different Categories of Demand Response Potentials. Energy 2019, 179, 280-294. [CrossRef]

15. Huang, W.; Zhang, N.; Kang, C.; Li, M.; Huo, M. From demand response to integrated demand response: Review and prospect of research and application. Prot. Control. Mod. Power Syst. 2019, 4, 12. [CrossRef]

16. Ventosa, M.; Linares, P.; Pérez-Arriaga, I.J. Power system economics. In Regulation of the Power Sector; Springer: Berlin/Heidelberg, Germany, 2013; pp. 47-123.

17. Cepeda, M.; Saguan, M. Assessing long-term effects of demand response policies in wholesale electricity markets. Int. J. Electr. Power Energy Syst. 2016, 74, 142-152. [CrossRef]

18. Sulaima, M.F.; Dahlan, N.Y.; Yasin, Z.M.; Rosli, M.M.; Omar, Z.; Hassan, M.Y. A review of electricity pricing in peninsular Malaysia: Empirical investigation about the appropriateness of Enhanced Time of Use (ETOU) electricity tariff. Renew. Sustain. Energy Rev. 2019, 110, 348-367. [CrossRef]

19. Ghadi, M.J.; Rajabi, A.; Ghavidel, S.; Azizivahed, A.; Li, L.; Zhang, J. From active distribution systems to decentralized microgrids: A review on regulations and planning approaches based on operational factors. Appl. Energy 2019, 253, 113543. [CrossRef]

20. Kwon, P.S.; Østergaard, P. Assessment and evaluation of flexible demand in a Danish future energy scenario. Appl. Energy 2014, 134, 309-320. [CrossRef]

21. Cruz, M.R.M.; Fitiwi, D.Z.; Santos, S.F.; Catalão, J.P.S. A comprehensive survey of flexibility options for supporting the low-carbon energy future. Renew. Sustain. Energy Rev. 2018, 97, 338-353. [CrossRef]

22. Gaffney, F.; Deane, J.P.; Gallachóir, B.P.Ó. Reconciling high renewable electricity ambitions with market economics and system operation: Lessons from Ireland's power system. Energy Strategy Rev. 2019, 26, 100381. [CrossRef]

23. Chinmoy, L.; Iniyan, S.; Goic, R. Modeling wind power investments, policies and social benefits for deregulated electricity market-A review. Appl. Energy 2019, 242, 364-377. [CrossRef]

24. Vahid-Ghavidel, M.; Javadi, M.S.; Santos, S.F.; Gough, M.; Mohammadi-Ivatloo, B.; Shafie-Khah, M.; Catalão, J.P.S. Novel Hybrid Stochastic-Robust Optimal Trading Strategy for a Demand Response Aggregator in the Wholesale Electricity Market. IEEE Trans. Ind. Appl. 2021, 57, 5488-5498. [CrossRef] 
25. Qaderi-Baban, P.; Menhaj, M.-B.; Dosaranian-Moghadam, M.; Fakharian, A. A Coordinated Performance of Power System Operated with Participants in Demand Response Programs Considering Environmental Pollution Constraints. J. Electr. Eng. Technol. 2021, 16, 15-29. [CrossRef]

26. Iria, J.; Soares, F.; Matos, M. Optimal supply and demand bidding strategy for an aggregator of small prosumers. Appl. Energy 2018, 213, 658-669. [CrossRef]

27. Burger, S.; Chaves-Ávila, J.P.; Batlle, C.; Pérez-Arriaga, I.J. A review of the value of aggregators in electricity systems. Renew. Sustain. Energy Rev. 2017, 77, 395-405. [CrossRef]

28. Iria, J.; Scott, P.; Attarha, A.; Gordon, D.; Franklin, E. MV-LV network-secure bidding optimisation of an aggregator of prosumers in real-time energy and reserve markets. Energy 2021, 242, 122962. [CrossRef]

29. Hu, J.; Yang, G.; Ziras, C.; Kok, K. Aggregator operation in the balancing market through network-constrained transactive energy. IEEE Trans. Power Syst. 2018, 34, 4071-4080. [CrossRef]

30. Okur, Ö.; Voulis, N.; Heijnen, P.; Lukszo, Z. Aggregator-mediated demand response: Minimizing imbalances caused by uncertainty of solar generation. Appl. Energy 2019, 247, 426-437. [CrossRef]

31. Moghaddam, S.Z.; Akbari, T. Network-constrained optimal bidding strategy of a plug-in electric vehicle aggregator: A stochastic/robust game theoretic approach. Energy 2018, 151, 478-489. [CrossRef]

32. Machamint, V.; Oureilidis, K.; Efthymiou, V.; Georghiou, G.E. Investigation of the Role of an Aggregator Operating in the European Spot and Balancing Markets; the Case of an Island. In Proceedings of the 2018 15th International Conference on the European Energy Market (EEM), Lodz, Poland, 27-29 June 2018; pp. 1-5.

33. Parvania, M.; Fotuhi-Firuzabad, M.; Shahidehpour, M. Optimal demand response aggregation in wholesale electricity markets. IEEE Trans. Smart Grid 2013, 4, 1957-1965. [CrossRef]

34. Soares, T.; Sousa, T.; Andersen, P.B.; Pinson, P. Optimal offering strategy of an EV aggregator in the frequency-controlled normal operation reserve market. In Proceedings of the 2018 15th International Conference on the European Energy Market (EEM), Lodz, Poland, 27-29 June 2018; pp. 1-6.

35. Wang, X.; Huang, T.; Zhang, S.H. Equilibrium Analysis of Electricity Market Considering Penalties for Wind Power's Bidding Deviation. Power Syst. Technol. 2016, 40, 602-607.

36. Brown, M.A.; Chapman, O. The size, causes, and equity implications of the demand-response gap. Energy Policy 2021, $158,112533$. [CrossRef]

37. Gellings, C.W. Evolving practice of demand-side management. J. Mod. Power Syst. Clean Energy 2017, 5, 1-9. [CrossRef]

38. Zhou, K.; Yang, S. Demand side management in China: The context of China's power industry reform. Renew. Sustain. Energy Rev. 2015, 47, 954-965. [CrossRef]

39. Renani, Y.K.; Ehsan, M.; Shahidehpour, M. Optimal transactive market operations with distribution system operators. IEEE Trans. Smart Grid 2017, 9, 6692-6701. [CrossRef]

40. Khan, I. Energy-saving behaviour as a demand-side management strategy in the developing world: The case of Bangladesh. Int. J. Energy Environ. Eng. 2019, 10, 493-510. [CrossRef]

41. Harish, V.S.K.V.; Kumar, A. Planning and implementation strategy of Demand Side Management in India. In Proceedings of the 2014 First International Conference on Automation, Control, Energy and Systems (ACES), Adisaptagram, India, 1-2 February 2014; p. 1.

42. Chassin, D.P.; Rondeau, D. Aggregate modeling of fast-acting demand response and control under real-time pricing. Appl. Energy 2016, 181, 288-298. [CrossRef]

43. Tahir, M.; Haoyong, C.; Ibn, I.; Ali, N.; Ullah, S. Demand Response Programs Significance, Challenges and Worldwide Scope in Maintaining Power System Stability. Int. J. Adv. Comput. Sci. Appl. (IJACSA) 2018, 9. [CrossRef]

44. Chuang, A.S.; Gellings, C.W. Demand-Side Integration in a Restructured Electric Power Industry. In Proceedings of the 42nd International Conference on Large High Voltage Electric Systems 2008, CIGRE, Paris, France, 24-29 August 2008.

45. Logenthiran, T.; Srinivasan, D. Multi-Agent System for Demand Side Management in Smart Grid. In Proceedings of the 2011 IEEE Ninth International Conference on Power Electronics and Drive Systems, Singapore, 5-8 December 2011.

46. Pasetti, M.; Rinaldi, S.; Manerba, D. A Virtual Power Plant Architecture for the Demand-Side Management of Smart Prosumers. Appl. Sci. 2018, 8, 432. [CrossRef]

47. Longe, O. Time Programmable Smart Devices for Peak Demand Reduction of Smart Homes in a Microgrid. In Proceedings of the 2014 IEEE 6th International Conference on Adaptive Science \& Technology (ICAST), Lagos, Nigeria, 29-31 October 2014.

48. Li, H.; Wang, Z.; Hong, T.; Piette, M.A. Energy Flexibility of Residential Buildings: A Systematic Review of Characterization and Quantification Methods and Applications. Adv. Appl. Energy 2021, 3, 100054. [CrossRef]

49. Rahman, M.M.; Hettiwatte, S.; Shafiullah, G.M.; Arefi, A. An analysis of the time of use electricity price in the residential sector of Bangladesh. Energy Strategy Rev. 2017, 18, 183-198. [CrossRef]

50. Ye, B.; Ge, F.; Rong, X.; Li, L. The influence of nonlinear pricing policy on residential electricity demand-A case study of Anhui residents. Energy Strategy Rev. 2016, 13, 115-124. [CrossRef]

51. Pallonetto, F.; De Rosa, M.; Milano, F.; Finn, D.P. Demand response algorithms for smart-grid ready residential buildings using machine learning models. Appl. Energy 2019, 239, 1265-1282. [CrossRef]

52. Touma, H.J.; Mansor, M.; Rahman, M.S.A.; Kumaran, V.; Mokhlis, H.B.; Ying, Y.J.; Hannan, M.A. Energy management system of microgrid: Control schemes, pricing techniques, and future horizons. Int. J. Energy Res. 2021, 45, 12728-12739. [CrossRef] 
53. Xu, B.; Wang, J.; Guo, M.; Lu, J.; Li, G.; Han, L. A hybrid demand response mechanism based on real-time incentive and real-time pricing. Energy 2021, 231, 120940. [CrossRef]

54. Cao, K.; Choi, T.M. Optimal Trade-in Return Policies: Is it Wise to be Generous? Prod. Oper. Manag. 2021. [CrossRef]

55. Hajibandeh, N.; Ehsan, M.; Soleymani, S.; Shafie-khah, M.; Catalão, J.P.S. The Mutual Impact of Demand Response Programs and Renewable Energies: A Survey. Energies 2017, 10, 1353. [CrossRef]

56. Olsen, D.; Kiliccote, S.; Sohn, M.; Dunn, L.; Piette, M.A. Taxonomy for Modeling Demand Response Resources; Lawrence Berkeley National Laboratory: Berkeley, CA, USA, 2014.

57. Lynch, M.Á.; Nolan, S.; Devine, M.T.; O'Malley, M. The impacts of demand response participation in capacity markets. Appl. Energy 2019, 250, 444-451. [CrossRef]

58. Khan, A.S.M.; Verzijlbergh, R.A.; Sakinci, O.C.; De Vries, L.J. How do demand response and electrical energy storage affect (the need for) a capacity market? Appl. Energy 2018, 214, 39-62. [CrossRef]

59. Motalleb, M.; Thornton, M.; Reihani, E.; Ghorbani, R. Providing frequency regulation reserve services using demand response scheduling. Energy Convers. Manag. 2016, 124, 439-452. [CrossRef]

60. Gjorgievski, V.Z.; Markovska, N.; Abazi, A.; Duić, N.J.R.; Reviews, S.E. The potential of power-to-heat demand response to improve the flexibility of the energy system: An empirical review. Renew. Sustain. Energy Rev. 2021, 138, 110489. [CrossRef]

61. Aalami, H.A.; Khatibzadeh, A. Regulation of market clearing price based on nonlinear models of demand bidding and emergency demand response programs. Int. Trans. Electr. Energy Syst. 2016, 26, 2463-2478. [CrossRef]

62. Chen, Y.; Zhang, L.; Xu, P.; Di Gangi, A. Electricity demand response schemes in China: Pilot study and future outlook. Energy 2021, 224, 120042. [CrossRef]

63. Dallinger, B.; Schwabeneder, D.; Lettner, G.; Auer, H. Socio-economic benefit and profitability analyses of Austrian hydro storage power plants supporting increasing renewable electricity generation in Central Europe. Renew. Sustain. Energy Rev. 2019, 107, 482-496. [CrossRef]

64. Bracco, S.; Delfino, F.; Pampararo, F.; Robba, M.; Rossi, M. A mathematical model for the optimal operation of the University of Genoa Smart Polygeneration Microgrid: Evaluation of technical, economic and environmental performance indicators. Energy 2014, 64, 912-922. [CrossRef]

65. De Christo, T.M.; Perron, S.; Fardin, J.F.; Simonetti, D.S.L.; de Alvarez, C.E. Demand-side energy management by cooperative combination of plans: A multi-objective method applicable to isolated communities. Appl. Energy 2019, 240, 453-472. [CrossRef]

66. Eriksson, E.L.V.; Gray, E.M. Optimization and integration of hybrid renewable energy hydrogen fuel cell energy systems-A critical review. Appl. Energy 2017, 202, 348-364. [CrossRef]

67. Anderson, K.; Laws, N.D.; Marr, S.; Lisell, L.; Jimenez, T.; Case, T.; Li, X.; Lohmann, D.; Cutler, D. Quantifying and monetizing renewable energy resiliency. Sustainability 2018, 10, 933. [CrossRef]

68. Gazafroudi, A.S.; Shafie-khah, M.; Heydarian-Forushani, E.; Hajizadeh, A.; Heidari, A.; Corchado, J.M.; Catalão, J.P.S. Two-stage stochastic model for the price-based domestic energy management problem. Int. J. Electr. Power Energy Syst. 2019, 112, 404-416. [CrossRef]

69. O'Dwyer, E.; Pan, I.; Acha, S.; Shah, N. Smart energy systems for sustainable smart cities: Current developments, trends and future directions. Appl. Energy 2019, 237, 581-597. [CrossRef]

70. Minou, M.; Thanos, G.; Vasirani, M.; Ganu, T.; Jain, M.; Gylling, A. Evaluating demand response programs: Getting the key performance indicators right. In Proceedings of the International Workshop on Demand Response, Bangalore, India, 7-10 January 2013.

71. Gils, H.C. Assessment of the theoretical demand response potential in Europe. Energy 2014, 67, 1-18. [CrossRef]

72. Olmos, L.; Rodilla, P.; Fernandes, C.; Frias, P.; Ahcin, P.; Morch, A.; Ostos, P. Definition of Key Performance Indicators for the Assessment of Design Options. 2015. Available online: http://market4res.eu/wp-content/uploads/D3-3_20160111_KPI.pdf (accessed on 28 June 2021).

73. Pramangioulis, D.; Atsonios, K.; Nikolopoulos, N.; Rakopoulos, D.; Grammelis, P.; Kakaras, E. A Methodology for Determination and Definition of Key Performance Indicators for Smart Grids Development in Island Energy Systems. Energies 2019, 12, 242. [CrossRef]

74. Mohajeryami, S.; Schwarz, P.; Baboli, P.T. Including the behavioral aspects of customers in demand response model: Real time pricing versus peak time rebate. In Proceedings of the 2015 North American Power Symposium (NAPS), Charlotte, NC, USA, 4-6 October 2015; pp. 1-6.

75. Sharifi, R.; Fathi, S.H.; Anvari-Moghaddam, A.; Guerrero, J.M.; Vahidinasab, V. An economic customer-oriented demand response model in electricity markets. In Proceedings of the 2018 IEEE International Conference on Industrial Technology (ICIT), Lyon, France, 19-22 February 2018; pp. 1149-1153.

76. Jalili, H.; Sheikh-El-Eslami, M.K.; Moghaddam, M.P.; Siano, P. Modeling of demand response programs based on market elasticity concept. J. Ambient. Intell. Humaniz. Comput. 2018, 10, 2265-2276. [CrossRef]

77. Qu, X.; Hui, H.; Yang, S.; Li, Y.; Ding, Y. Price elasticity matrix of demand in power system considering demand response programs. In IOP Conference Series: Earth and Environmental Science; IOP Publishing: Bristol, UK, 2018.

78. Asadinejad, A.; Tomsovic, K. Optimal use of incentive and price based demand response to reduce costs and price volatility. Electr. Power Syst. Res. 2017, 144, 215-223. [CrossRef] 
79. Zin, A.A.B.M.; Moradi, M. An experimental investigation of price elasticity in electricity markets using a response surface methodology. Energy Effic. 2018, 12, 667-680. [CrossRef]

80. Müller, M.F.; Thompson, S.E.; Gadgil, A.J. Estimating the price (in)elasticity of off-grid electricity demand. Dev. Eng. 2018, 3, 12-22. [CrossRef]

81. Jiang, J.; Kou, Y.; Bie, Z.; Li, G. Optimal Real-Time Pricing of Electricity Based on Demand Response. Energy Procedia 2019, 159, 304-308. [CrossRef]

82. Boogen, N.; Datta, S.; Filippini, M. Dynamic models of residential electricity demand: Evidence from Switzerland. Energy Strategy Rev. 2017, 18, 85-92. [CrossRef]

83. Sharifi, R.; Anvari-Moghaddam, A.; Hamid Fathi, S.; Guerrero, J.; Vahidinasab, V. Economic Demand Response Model in Liberalized Electricity Markets with Respect to Flexibility of Consumers. IET Gener. Transm. Distrib. 2017, 11, 4291-4298. [CrossRef]

84. Chai, Y.; Xiang, Y.; Liu, J.; Gu, C.; Zhang, W.; Xu, W. Incentive-based demand response model for maximizing benefits of electricity retailers. J. Mod. Power Syst. Clean Energy 2019, 7, 1644-1650. [CrossRef]

85. Kaya, A.; Csala, D.; Sgouridis, S. Constant elasticity of substitution functions for energy modeling in general equilibrium integrated assessment models: A critical review and recommendations. Clim. Change 2017, 145, 27-40. [CrossRef]

86. Arnette, A.; Zobel, C.W. An optimization model for regional renewable energy development. Renew. Sustain. Energy Rev. 2012, 16, 4606-4615. [CrossRef]

87. Henao, F.; Cherni, J.A.; Jaramillo, P.; Dyner, I. A multicriteria approach to sustainable energy supply for the rural poor. Eur. J. Oper. Res. 2012, 218, 801-809. [CrossRef]

88. Amorim, F.; Pina, A.; Gerbelová, H.; Pereira da Silva, P.; Vasconcelos, J.; Martins, V. Electricity decarbonisation pathways for 2050 in Portugal: A TIMES (The Integrated MARKAL-EFOM System) based approach in closed versus open systems modelling. Energy 2014, 69, 104-112. [CrossRef]

89. Hussain, I.; Mohsin, S.; Basit, A.; Khan, Z.A.; Qasim, U.; Javaid, N. A Review on Demand Response: Pricing, Optimization, and Appliance Scheduling. Procedia Comput. Sci. 2015, 52, 843-850. [CrossRef]

90. Soroudi, A. Power System Optimization Modeling in GAMS; Springer: Berlin/Heidelberg, Germany, 2017 ; Volume 78.

91. Neves, D.; Pina, A.; Silva, C.A. Demand response modeling: A comparison between tools. Appl. Energy 2015, 146, 288-297. [CrossRef]

92. Ringkjøb, H.-K.; Haugan, P.M.; Solbrekke, I.M. A review of modelling tools for energy and electricity systems with large shares of variable renewables. Renew. Sustain. Energy Rev. 2018, 96, 440-459. [CrossRef]

93. Dagoumas, A.S.; Koltsaklis, N.E. Review of models for integrating renewable energy in the generation expansion planning. Appl. Energy 2019, 242, 1573-1587. [CrossRef]

94. Yu, M.; Hong, S.H. Incentive-based demand response considering hierarchical electricity market: A Stackelberg game approach. Appl. Energy 2017, 203, 267-279. [CrossRef]

95. Bouckaert, S.; Mazauric, V.; Maïzi, N. Expanding Renewable Energy by Implementing Demand Response. Energy Procedia 2014, 61, 1844-1847. [CrossRef]

96. Gottwalt, S.; Gärttner, J.; Schmeck, H.; Weinhardt, C. Modeling and Valuation of Residential Demand Flexibility for Renewable Energy Integration. IEEE Trans. Smart Grid 2017, 8, 2565-2574. [CrossRef]

97. Hajibandeh, N.; Ehsan, M.; Soleymani, S.; Shafie-khah, M.; Catalão, J.P.S. Modeling price- and incentive-based demand response strategies in the renewable-based energy markets. In Proceedings of the 2017 IEEE International Conference on Environment and Electrical Engineering, Milan, Italy, 6-9 June 2017; pp. 1-5.

98. Liu, T.; Zhang, D.; Wang, S.; Wu, T. Standardized modelling and economic optimization of multi-carrier energy systems considering energy storage and demand response. Energy Convers. Manag. 2019, 182, 126-142. [CrossRef]

99. Karimi, E.; Kazerani, M. Impact of demand response management on improving social welfare of remote communities through integrating renewable energy resources. In Proceedings of the 2017 IEEE 30th Canadian Conference on Electrical and Computer Engineering (CCECE), Windsor, ON, Canada, 30 April-3 May 2017; pp. 1-6.

100. Kumar, J.; Suryakiran, B.V.; Verma, A.; Bhatti, T.S. Analysis of techno-economic viability with demand response strategy of a grid-connected microgrid model for enhanced rural electrification in Uttar Pradesh state, India. Energy 2019, 178, 176-185. [CrossRef]

101. Xu, Q.; Ding, Y.; Zheng, A. An Optimal Dispatch Model of Wind-Integrated Power System Considering Demand Response and Reliability. Sustainability 2017, 9, 758. [CrossRef]

102. Conteh, A.; Lotfy, M.E.; Kipngetich, K.M.; Senjyu, T.; Mandal, P.; Chakraborty, S. An Economic Analysis of Demand Side Management Considering Interruptible Load and Renewable Energy Integration: A Case Study of Freetown Sierra Leone. Sustainability 2019, 11, 2828. [CrossRef]

103. Babonneau, F.; Caramanis, M.; Haurie, A. A linear programming model for power distribution with demand response and variable renewable energy. Appl. Energy 2016, 181, 83-95. [CrossRef]

104. Purvis, B.; Mao, Y.; Robinson, D. Three pillars of sustainability: In search of conceptual origins. Sustain. Sci. 2019, 14,681-695. [CrossRef]

105. Emas, R. The Concept of Sustainable Development: Definition and Defining Principles. In Global Sustainable Development Report, 2015 Edition; United Nations: New York, NY, USA, 2015. 
106. Tomislav, K. The Concept of Sustainable Development: From its Beginning to the Contemporary Issues. Zagreb Int. Rev. Econ. Bus. 2018, 21, 67-94. [CrossRef]

107. Ahmadi, S.; Fakehi, A.h.; vakili, A.; Haddadi, M.; Iranmanesh, S.H. A hybrid stochastic model based Bayesian approach for long term energy demand managements. Energy Strategy Rev. 2020, 28, 100462. [CrossRef]

108. Riva, F.; Tognollo, A.; Gardumi, F.; Colombo, E. Long-term energy planning and demand forecast in remote areas of developing countries: Classification of case studies and insights from a modelling perspective. Energy Strategy Rev. 2018, 20, 71-89. [CrossRef]

109. Zhou, K.; Wei, S. Time-of-use price model for user-side micro-grid based on power supply chain management. Energy Procedia 2018, 152, 51-56. [CrossRef]

110. Yildıran, U.; Kayahan, İ. Risk-averse stochastic model predictive control-based real-time operation method for a wind energy generation system supported by a pumped hydro storage unit. Appl. Energy 2018, 226, 631-643. [CrossRef]

111. Péan, T.; Salom, J.; Ortiz, J. Environmental and Economic Impact of Demand Response Strategies for Energy Flexible Buildings. In Proceedings of the 4th Building Simulation and Optimization Conference, Cambridge, UK, 11-12 September 2018.

112. Wang, Y.; Huang, Y.; Wang, Y.; Li, F.; Zhang, Y.; Tian, C. Operation Optimization in a Smart Micro-Grid in the Presence of Distributed Generation and Demand Response. Sustainability 2018, 10, 847. [CrossRef]

113. Ji, X.; Li, Y.; Yu, Y.; Fan, S. Optimal dispatching and game analysis of power grid considering demand response and pumped storage. Syst. Sci. Control. Eng. 2018, 6, 270-277. [CrossRef]

114. Sharma, S.; Durvasulu, V.; Celik, B.; Suryanarayanan, S.; Hansen, T.M.; Maciejewski, A.A.; Siegel, H.J. Metrics-Based Assessment of Sustainability in Demand Response. In Proceedings of the 2017 IEEE 19th International Conference on High Performance Computing and Communications, Bangkok, Thailand, 18-20 December 2017.

115. Hoffman, I.M.; Rybka, G.; Leventis, G.; Goldman, C.A.; Schwartz, L.; Billingsley, M.; Schiller, S. The Total Cost of Saving Electricity through Utility Customer-Funded Energy Efficiency Programs: Estimates at the National, State, Sector and Program Level; Technical Brief; Berkeley Lab: Berkeley, CA, USA, 2015; p. 22.

116. Caputo, S. Non-Energy Impacts Approaches and Values: An Examination of the Northeast, Mid-Atlantic, and Beyond; Northeast Energy Efficiency Partnerships: Lexington, MA, USA, 2017.

117. Duncan, J.; Burtraw, D. Does Integrated Resource Planning Effectively Integrate Demand-Side Resources? Resources for the Future (RFF): Washington, DC, USA, 2018; p. 28.

118. Mays, J. Missing incentives for flexibility in wholesale electricity markets. Energy Policy 2021, 149, 112010. [CrossRef]

119. Mills, A.D.; Levin, T.; Wiser, R.; Seel, J.; Botterud, A.J.R.; Reviews, S.E. Impacts of variable renewable energy on wholesale markets and generating assets in the United States: A review of expectations and evidence. Renew. Sustain. Energy Rev. 2020, 120, 109670. [CrossRef]

120. Layson, S.K. The Increasing Returns to Scale CES Production Function and the Law of Diminishing Marginal Returns. South. Econ. J. 2014, 82, 408-415. [CrossRef]

121. Cao, J.; Ho, M.S.; Ma, R. Analyzing carbon pricing policies using a general equilibrium model with production parameters estimated using firm data. Energy Econ. 2020, 92, 104958. [CrossRef]

122. Wang, A.; Hu, S.; Lin, B. Can environmental regulation solve pollution problems? Theoretical model and empirical research based on the skill premium. Energy Econ. 2021, 94, 105068. [CrossRef]

123. Pothen, F.; Hübler, M. A forward calibration method for analyzing energy policy in new quantitative trade models. Energy Econ. 2021, 100, 105352. [CrossRef]

124. Lin, B.; Wu, W. The impact of electric vehicle penetration: A recursive dynamic CGE analysis of China. Energy Econ. 2021, 94, 105086. [CrossRef]

125. Ahn, K.; Chu, Z.; Lee, D. Effects of renewable energy use in the energy mix on social welfare. Energy Econ. 2021, 96, 105174. [CrossRef]

126. Lagomarsino, E. Estimating elasticities of substitution with nested CES production functions: Where do we stand? Energy Econ. 2020, 88, 104752. [CrossRef]

127. Morales, J.M.; Conejo, A.J.; Madsen, H.; Pinson, P.; Zugno, M. Integrating Renewables in Electricity Markets: Operational Problems; Springer Science \& Business Media: Berlin/Heidelberg, Germany, 2013; Volume 205.

128. Daraeepour, A.; Kazempour, S.J.; Patiño-Echeverri, D.; Conejo, A.J. Strategic demand-side response to wind power integration. IEEE Trans. Power Syst. 2015, 31, 3495-3505. [CrossRef]

129. McPherson, M.; Stoll, B. Demand response for variable renewable energy integration: A proposed approach and its impacts. Energy 2020, 197, 117205. [CrossRef]

130. Helali, K.; Kalai, M. Estimate of the Elasticities of Substitution of the CES and Translog Production Functions in Tunisia. Int. J. Econ. Bus. Res. 2015, 9, 245-253. [CrossRef]

131. Eggleston, S.; Buendia, L.; Miwa, K.; Ngara, T.; Tanabe, K. 2006 IPCC Guidelines for National Greenhouse Gas Inventories; U.S. Department of Energy, Office of Scientific and Technical Information: Washinton, DC, USA, 2006.

132. Carrara, S.; Marangoni, G. Including system integration of variable renewable energies in a constant elasticity of substitution framework: The case of the WITCH model. Energy Econ. 2017, 64, 612-626. [CrossRef]

133. Fan, J.; Li, J.; Wu, Y.; Wang, S.; Zhao, D. The effects of allowance price on energy demand under a personal carbon trading scheme. Appl. Energy 2016, 170, 242-249. [CrossRef] 
134. Zha, D.; Kavuri, A.S.; Si, S. Energy biased technology change: Focused on Chinese energy-intensive industries. Appl. Energy 2017, 190, 1081-1089. [CrossRef]

135. Sharifi, R.; Anvari-Moghaddam, A.; Fathi, S.H.; Vahidinasab, V. A Flexible Responsive Load Economic Model for Industrial Demands. Processes 2019, 7, 147. [CrossRef]

136. Brockway, P.E.; Heun, M.K.; Santos, J.; Barrett, J.R. Energy-extended CES aggregate production: Current aspects of their specification and econometric estimation. Energies 2017, 10, 202. [CrossRef]

137. Kirkerud, J.; Nagel, N.O.; Bolkesjø, T.F. The role of demand response in the future renewable northern European energy system. Energy 2021, 235, 121336. [CrossRef] 